\title{
Application of Magnetic Composites in Removal of Tetracycline through Adsorption and Advanced Oxidation Processes (AOPs): A Review
}

\author{
Beibei Fan ${ }^{1}$, Yi Tan ${ }^{1}$, Jingxin Wang ${ }^{2}$, Bangxi Zhang ${ }^{3, *}$, Yutao Peng ${ }^{1,4, *}$, Chengpeng Yuan ${ }^{1}$, Chungyu Guan ${ }^{5}$, \\ Xing Gao ${ }^{6}$ and Shihao Cui ${ }^{1}$
}

1 Beijing Key Laboratory of Farmyard Soil Pollution Prevention-Control and Remediation, College of Resources and Environmental Sciences, China Agricultural University, Beijing 100193, China; beifanbei123@163.com (B.F.); yitan0802@foxmail.com (Y.T.); 18605846885@163.com (C.Y.); shihaoc@foxmail.com (S.C.)

2 Guangzhou Huashang College, Guangzhou 511300, China; wangjingxin0106@foxmail.com

3 Institute of Agriculture Resources and Environment, Guizhou Provincial Academy of Agricultural Sciences, Guiyang 550006, China

4 School of Agriculture, Sun Yat-sen University, Shenzhen 523758, China

5 Department of Environmental Engineering, National Ilan University, Yilan 260, Taiwan; zenithal2010@gmail.com

6 State Key Laboratory for Pollution Control and Reuse, School of Environmental Science and Engineering, Tongii University, Shanghai 200092, China; gaoxing1509@163.com

* Correspondence: zbx@cau.edu.cn (B.Z.); ytaopeng@cau.edu.cn (Y.P.)

check for updates

Citation: Fan, B.; Tan, Y.; Wang, J.; Zhang, B.; Peng, Y.; Yuan, C.; Guan, C.; Gao, X.; Cui, S. Application of Magnetic Composites in Removal of Tetracycline through Adsorption and Advanced Oxidation Processes (AOPs): A Review. Processes 2021, 9, 1644. https://doi.org/10.3390/ pr9091644

Academic Editor: Guining Lu

Received: 18 August 2021

Accepted: 8 September 2021

Published: 13 September 2021

Publisher's Note: MDPI stays neutral with regard to jurisdictional claims in published maps and institutional affiliations.

Copyright: (c) 2021 by the authors. Licensee MDPI, Basel, Switzerland. This article is an open access article distributed under the terms and conditions of the Creative Commons Attribution (CC BY) license (https:/ / creativecommons.org/licenses/by/ $4.0 /)$.

\begin{abstract}
Water pollution induced by the tetracycline (TC) has caused global increasing attention owing to its extensive use, environmental persistence, and potential harm for human health. Adsorption and advanced oxidation processes (AOPs) have been promising techniques for TC removal due to ideal effectiveness and efficiency. Magnetic composites (MCs) which exploit the combined advantages of nano scale, alternative sources, easy preparation, and separation from wastewater are widely used for catalysis and adsorption. Herein, we intensively reviewed the available literature in order to provide comprehensive insight into the applications and mechanisms of MCs for removal of TC by adsorption and AOPs. The synthesis methods of MCs, the TC adsorption, and removal mechanisms are fully discussed. MCs serve as efficient adsorbents and photocatalysts with superior performance of photocatalytic performance in TC degradation. In addition, the TC can be effectively decomposed by the Fenton-based and $\mathrm{SO}_{4}{ }^{\bullet-}$ mediated oxidation under catalysis of the reported MCs with excellent catalytic performance. Based on the existing literature, we further discuss the challenge and future perspectives in MCs-based adsorption and AOPs in removing TC.
\end{abstract}

Keywords: magnetic composites; tetracycline; adsorption; advanced oxidation processes

\section{Introduction}

Antibiotics are widely used in industries such as medicine, animal husbandry, and aquaculture to kill various kinds of pathogenic bacteria [1,2]. Now, antibiotics considered as emerging environmental pollutants have received more attention in the world due to their chronic undesirable effect on the health of human beings and aquatic biota [3,4]. Tetracycline (TC) is one of the main antibiotics groups used for veterinary purposes, human therapy, and agricultural purposes $[5,6]$. TC was the most frequently used antibiotics and widely distributed in the aquatic environment $[7,8]$. However, for humans or animals, it is difficult to metabolize TC, and most of the TC is excreted in the form of original drug or parent compounds in the environment $[9,10]$. As a result, more than $50 \%$ of the TC enter the environment as metabolites [1,11]. Even humans and animals can excrete $50-80 \%$ of the administered dose of TC as the parent compound through urine [7]. Moreover, TC has been detected widely in different water environments: mariculture 
(0.2-259.1 $\left.\mathrm{ng} \mathrm{L}^{-1}\right)$ [12], drinking water sources (11.16 $\left.\mathrm{ng} \mathrm{L}^{-1}\right)$ [13], and groundwater $\left(0.4 \mathrm{ug} \mathrm{L}^{-1}\right)$ [14]. Long-term residual TC may result in the proliferation and transmission of drug-resistant bacterial flora, which may in turn affect the structure and function of ecosystems [15]. The long-term harmful effects of residual TC on human health and ecosystems have become a serious concern [1]. For example, the emergence of these antibiotic residues inhibits the growth and development of aquatic species, and may over-accumulate in the food chain to lead to joint disease, nephropathy, endocrine disruption, and central nervous system defect $[16,17]$. The techniques for removing TC from water include biological processes [18], coagulation [3], sedimentation [19], electrochemical processes [20], membrane techniques [21], advanced oxidation processes [22], chlorination [23], and adsorption [4], which are summarized in Figure 1. However, most of conventional treatment processes have an inherent disadvantage for removing TC [24]. For example, the chlorination method could produce intermediate products with higher toxicity [25], membrane techniques did not actually remove or degrade the TC, but only transferred it to a new phase, which could cause secondary contamination [26], and the mass transfer efficiency of electrochemical oxidation on metal electrodes was restricted for practical application [27,28]. Among these, adsorption and advanced oxidation processes were relative cost-effective and efficient methods. Adsorption is considered to be one of the most promising methods to remove TC from aqueous solutions due to its attractive advantages such as low-cost effectiveness, environmental friendliness, and convenient operation [29,30]. Ahamed et al. [28] prepared magnetic nanocomposites with a high surface area of $376 \mathrm{~m}^{2} \mathrm{~g}^{-1}$, high pore volume of $0.38 \mathrm{~cm}^{3} \mathrm{~g}^{-1}$, and the adsorption capacity of $215.3 \mathrm{mg} \mathrm{g}^{-1}$ for TC. Advanced oxidation processes (AOPs) (photocatalysis, electrochemical oxidation method, Fenton-like method, etc.) are widely used to remove TC due to high efficiency, cost-effectiveness, and environmental friendliness [31-33]. Sun et al. [34] found that the N-deficient g- $\mathrm{C}_{3} \mathrm{~N}_{4} / \mathrm{PS}\left(\mathrm{g}-\mathrm{CN}_{\mathrm{x}} / \mathrm{PS}\right)$ system displayed a high efficiency of TC degradation under photocatalysis with over $80 \%$ after three recycles, indicating that the carbon nitride based photocatalyst possessed excellent photocatalytic stability. Numerous catalysts are reported to be utilized in AOPs, such as $\mathrm{TiO}_{2}$ [35], $\mathrm{WO}_{3}$ [36], $\mathrm{Fe}_{3} \mathrm{O}_{4}$ [37], $\mathrm{ZnO}$ [38], $\mathrm{Ag}_{3} \mathrm{PO}_{4}$ [39], graphene [40], $\mathrm{SnO}_{2}$ [41], etc. However, most of these catalysts were hard to be separated from water [42,43] and tended to agglomerate [37]. Under these circumstances, magnetic materials have garnered considerable interest as they can overcome the above shortcomings of normal catalyst [44] and exhibit the enhanced degradation efficiency via the synergistic effect of the combination of the host and guest compounds [45].

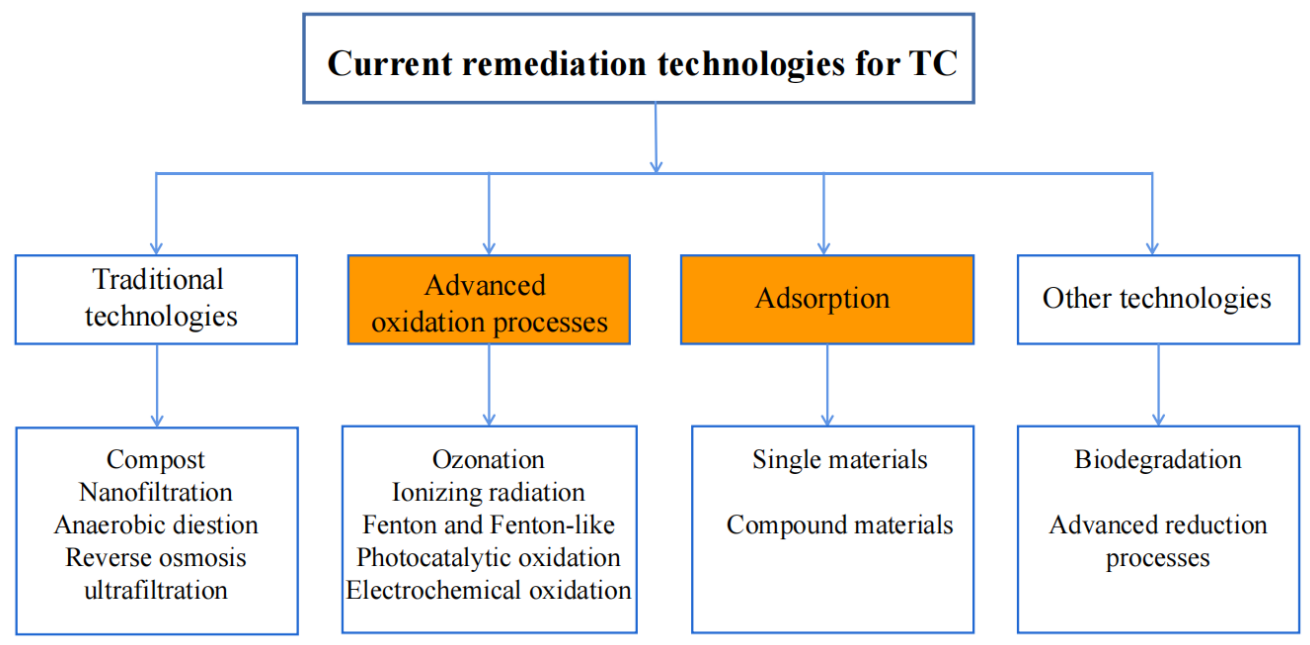

Figure 1. Overview of existing remediation technologies for controlling the TC pollution.

Magnetic composites (MCs) (such as magnetic biochar, magnetic nanomaterials, magnetic chitosan, etc.) are broadly utilized in adsorption and AOPs due to their high surface area, porous structure, convenient separation, and recycling [1,46-48]. Transition metal 
salts, natural iron ores, and iron oxides were commonly used magnetic precursor. When the loaded magnetic species have strong magnetism, the magnetic performance of MCs will be relatively superior [49]. For example, Li et al. [50] prepared magnetic biochar composites by pyrolysis of siderite and rice husk and the presence of specific saturation magnetization was $9.45 \mathrm{emu} / \mathrm{g}$. Sherlala et al. [51] found that the chitosan-magnetic-graphene oxide (CMGO) nanocomposite had an excellent saturation magnetization $(49.30 \mathrm{emu} / \mathrm{g})$, which could be easily separated from the solution by the application of an external magnetic field. The methods of MCs production include hydrothermal [52], coprecipitation [37] and sol-gel methods [53], etc. In general, the pure magnetism has the disadvantages of bad dispersion, poor separation effect, weak electron transfer ability, and low catalytic activity. To overcome the above disadvantages, researchers used different precursors and original magnets to prepare MCs, most of which were fictionalizing by porous or photoreceptive particles, such as activated carbon [37], graphitic carbon nitride [24], and titanion oxide [54], to enhance their feasibility for TC removal from wastewater. In some cases, original magnets were combined with porous supporters with high specific surface area to address the problem that magnets had a strong tendency to agglomerate [37]. In other cases, non-magnetic catalyst could be coupled with magnets to facilitate their recycling efficiency [52]. In terms of TC removal from wastewater, even though diverse MCs were developed for TC removal from wastewater, there was no a systematic review on the fabrication of MCs and the mechanisms of their application in TC removal.

To date, applications of MCs in water treatment has aroused considerably the interest of researchers, as several previous reviews on MCs have been published in the past few years [24,49,55-57]. For example, Li et al. [58] only focused on the synthesis and environmental remediation of magnetic biochar and Minile et al. [24] only summarized graphene-based materials to remove TC in aqueous solution by photocatalytic degradation and adsorption. The above reviews only focused on MCs based on single matrix, or a certain AOPs technique, but no review systematically introduced the degradation of a pollutant by various MCs via AOPs.

In light of this, we focused more attention on the applications and mechanisms of MCs for TC removal through adsorption and AOPs based published literature by summarizing the reported MCs for TC removal by absorption and AOPs. Firstly, we discuss the preparation methods of magnetic materials and categorizing the MCs. Secondly, we introduce the possible removal mechanisms between TC and MCs by adsorption and AOPs degradation. Thirdly, we investigate the synergistic effect between components during the degradation process. Finally, the possible challenges and outlook to appreciate more prospective improvements in similar future efforts are presented. This review may fulfill the existing knowledge gaps and provide favorable suggestions in TC removal from wastewater for future studies.

\section{Different Kinds of MCs and Their Fabrication Methods}

Previous reviews have summarized in details the application and development prospects of MCs in various fields. Brião et al. [59] introduced chitosan-based magnetic adsorbents to remove toxic heavy metals. Jacinto et al. [60] focused on the main synthesis processes of magnetic photocatalysts, and their effect on the catalyst morphology, degradation efficiency, and recycling. In this review, we briefly introduce the categories and synthesis methods of MCs for TC removal.

\subsection{Types of Magnetic Materials}

The precursors of MCs have a wide range of sources, such as biochar, activated carbon, chitosan, cellulose and artificial polymer. For example, Bao et al. [61] used the coprecipitation method to successfully synthesize magnetic illite clay-composite material $\left(\mathrm{Fe}_{3} \mathrm{O}_{4} @\right.$ illite). Bai et al. [62] modified copper ferrite on the surface of molybdenum disulfide to prepare $\mathrm{MoS}_{2} / \mathrm{CuFe}_{2} \mathrm{O}_{4}$ nanocomposites. According to the classification method of MCs such as magnetic biochar and chitosan-based MCs, and combining the precursors of MCs, 
this review would divide MCs into four categories: carbon-based MCs, polymer-based MCs, metal-organic framework (MOFs) based MCs, and others. The specific types of MCs are shown in Figure 2.

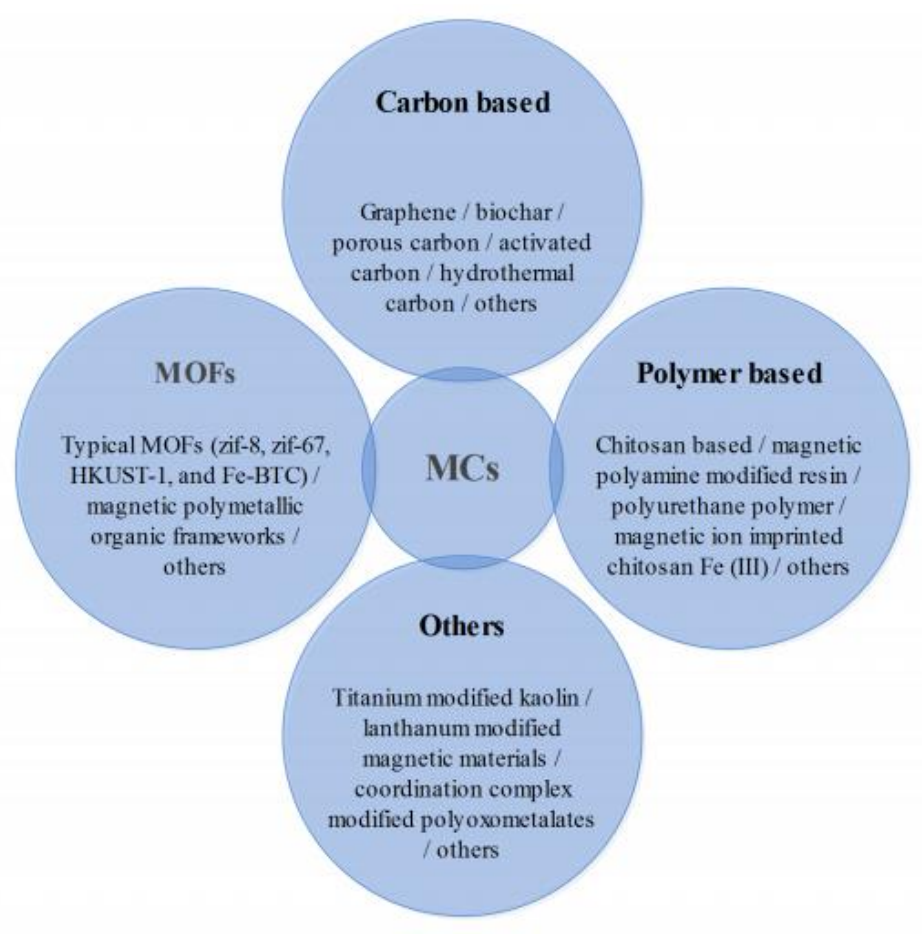

Figure 2. Categories of magnetic composites.

\subsection{Synthesis Methods for MCs}

There are many common preparation methods for MCs, including: pyrolysis, coprecipitation, hydrothermal/solgel, sonochemica, impregnation, post-crosslinking, amination, polymerization, in-situ precipitation, and oxidization. Diverse preparation methods for MCs in reported articles for TC removal are summarized in Table 1.

Table 1. The main preparation methods for magnetic materials.

\begin{tabular}{|c|c|c|c|c|}
\hline Material Category & Species & Magnetic Materials & Synthesis Techniques & References \\
\hline \multirow{11}{*}{$\begin{array}{c}\text { Carbon-based } \\
\text { magnetic materials }\end{array}$} & Graphene & $\begin{array}{l}\text { Sodium citrate coated } \\
\mathrm{Fe}_{3} \mathrm{O}_{4} \text { nanoparticles }\end{array}$ & Pyrolysis, co-precipitation & [54] \\
\hline & Graphene & $\begin{array}{l}\text { Thiourea-dioxide-reduced magnetic } \\
\text { graphene oxide }\end{array}$ & Pyrolysis, co-precipitation & [63] \\
\hline & Graphene & $\begin{array}{l}\text { Nitrilotriacetic acid-functionalized } \\
\text { magnetic graphene oxide }\end{array}$ & $\begin{array}{l}\text { Pyrolysis, co-precipitation, } \\
\text { Hydrothermal/Solgel }\end{array}$ & [64] \\
\hline & Graphene & $\begin{array}{l}\text { Magnetic graphene } \\
\text { oxide/ZnO nanocomposites }\end{array}$ & $\begin{array}{l}\text { Pyrolysis, co-precipitation, } \\
\text { Hydrothermal/Solgel }\end{array}$ & [65] \\
\hline & Biochar & $\begin{array}{l}\mathrm{MnFe}_{2} \mathrm{O}_{4} / \text { activated carbon } \\
\text { magnetic composite }\end{array}$ & Pyrolysis, co-precipitation & {$[66]$} \\
\hline & Biochar & $\begin{array}{l}\text { Magnetic porous carbon from } \\
\text { waste hydrochar }\end{array}$ & Pyrolysis & [67] \\
\hline & Biochar & $\begin{array}{l}\text { Sugarcane bagasse magnetic } \\
\text { carbon composites }\end{array}$ & Pyrolysis & [68] \\
\hline & Biochar & Activated sawdust hydrochar & Pyrolysis & [69] \\
\hline & Biochar & Magnetic chicken bone biochar & Pyrolysis, co-precipitation & [70] \\
\hline & Biochar & Alkali-acid modified magnetic biochar & $\begin{array}{c}\text { Pyrolysis, } \\
\text { hydrothermal/solgel }\end{array}$ & [71] \\
\hline & Biochar & $\begin{array}{l}\text { Magnetic carbon-coated cobalt } \\
\text { oxide nanoparticles }\end{array}$ & Sonochemical, pyrolysis & [72] \\
\hline
\end{tabular}


Table 1. Cont.

\begin{tabular}{|c|c|c|c|c|}
\hline Material Category & Species & Magnetic Materials & Synthesis Techniques & References \\
\hline & Biochar & $\begin{array}{l}\text { Modification and magnetization of rice } \\
\text { straw derived biochar }\end{array}$ & $\begin{array}{c}\text { Pyrolysis, } \\
\text { impregnation method }\end{array}$ & [47] \\
\hline & Biochar & $\begin{array}{l}\text { Ferroferric oxide nanoparticles assisted } \\
\text { powdered activated carbon }\end{array}$ & Co-precipitation & {$[30]$} \\
\hline & Biochar & $\begin{array}{l}\text { Biochar-supported iron-copper bimetallic } \\
\text { composite activating oxygen system }\end{array}$ & Pyrolysis, co-precipitation & [73] \\
\hline & Biochar & $\begin{array}{l}\text { Hydrothermal synthesis of magnetic } \\
\text { sludge biochar }\end{array}$ & $\begin{array}{c}\text { Pyrolysis, } \\
\text { Hydrothermal/solgel }\end{array}$ & {$[74]$} \\
\hline \multirow{6}{*}{$\begin{array}{l}\text { Polymer-based } \\
\text { magnetic materials }\end{array}$} & Chitosan & $\begin{array}{l}\text { Carbon disulfide-modified magnetic } \\
\text { ion-imprinted chitosan-Fe(III) }\end{array}$ & \multirow{2}{*}{$\begin{array}{l}\text { Co-precipitation, } \\
\text { Hydrothermal/solgel } \\
\text { Hydrothermal/solgel, } \\
\text { copolymerization, } \\
\text { post-crosslinking, } \\
\text { and amination }\end{array}$} & [69] \\
\hline & Resin & Novel magnetic multi-amine resins & & {$[75]$} \\
\hline & $\begin{array}{l}\text { Urethane } \\
\text { polymer }\end{array}$ & $\begin{array}{l}\text { Sustainable magnetic polyurethane } \\
\text { polymer nanocomposite }\end{array}$ & Co-precipitation & {$[76]$} \\
\hline & Chitosan & Chitosan based magnetic nanocomposite & $\begin{array}{l}\text { Copolymerization, } \\
\text { sonochemical, } \\
\text { hydrothermal/solgel }\end{array}$ & [46] \\
\hline & Chitosan & $\begin{array}{c}\mathrm{NiFe}_{2} \mathrm{O}_{4} \text {-COF-chitosan- } \\
\text { terephthalaldehyde } \\
\text { nanocomposites film }\end{array}$ & Sonochemical & [77] \\
\hline & Resin & magnetic multi-amine decorated resin & $\begin{array}{l}\text { Co-precipitation, } \\
\text { polymerization, } \\
\text { post-crosslinking reactions, } \\
\text { and amination. }\end{array}$ & [5] \\
\hline \multirow[t]{2}{*}{ MOFs } & & MOFs-chitosan composite beads & \multirow{2}{*}{$\begin{array}{l}\text { Hydrothermal reaction or } \\
\text { solvothermal reaction } \\
\text { Solvothermal method, }\end{array}$} & {$[78]$} \\
\hline & & Fe-based MOFs & & [79] \\
\hline \multirow{3}{*}{ Others } & Magnetic ads & $\begin{array}{l}\text { orbent constructed from the loading of amino } \\
\text { functionalized } \mathrm{Fe}_{3} \mathrm{O}_{4}\end{array}$ & & {$[80]$} \\
\hline & & La-modified magnetic composite & \multirow{2}{*}{$\begin{array}{l}\text { Co-precipitation } \\
\text { In-situ precipitation } \\
\text { and oxidization }\end{array}$} & [81] \\
\hline & Co-existing $\mathrm{T}$ & $\mathrm{O}_{2}$ nanoparticles magnetically modified kaolin & & {$[82]$} \\
\hline
\end{tabular}

Carbon-based MCs were mainly prepared by pyrolysis and co-precipitation. Pyrolysis was the main method to produce carbon-based magnetic composites, while co-precipitation had the advantages of scalable, simple, and easy size/morphology control. For example, Yu et al. [54] and Yang et al. [63] prepared thiourea dioxide reduced magnetic graphene oxide by pyrolysis and co-precipitation. In addition, polymer-based MCs were often prepared by various methods, such as co-precipitation, hydrothermal/solgel, sonochemical, and so on. The materials prepared by sonochemical had high efficiency and fine particle size, and hydrothermal/solgel had the advantages of high yield, water-based medium, scalability, and energy saving. For MOFs-based MCs, pyrolysis was the main method to prepare MOFs-based MCs. For example, Xiao et al. [2] prepared Nico/ $\mathrm{Fe}_{3} \mathrm{O}_{4}$-MOF-74 composite by pyrolysis. Besides, there are other preparation methods to be used. For example, Zhao et al. [78] prepared MOF-chitosan composite beads by hydrothermal reaction or solvothermal reaction.

There are also some magnetic composites that do not belong to the above three types. Their preparation methods could change greatly with the different research materials. For example, Wang et al. [83] and others prepared co-existing $\mathrm{TiO}_{2}$ nanoparticles magnetically modified kaolin by in-situ precision. Mi et al. [81] prepared La-modified magnetic composite by co-precipitation. 


\section{Applications of MCs for TC Adsorption}

Up to date, many research articles have focused on applications of MCs for TC removal. Previous studies on the application of MCs for TC removal by adsorption in aqueous solution are summarized in Table 2 .

Table 2. Performance of diverse magnetic materials for TC adsorption.

\begin{tabular}{|c|c|c|c|c|c|c|c|c|}
\hline Material & $\begin{array}{l}\text { Initial Concentration } \\
\text { of } \mathrm{TC}(\mathrm{mg} / \mathrm{L})\end{array}$ & $\begin{array}{l}\text { Dosage } \\
(\mathrm{g} / \mathrm{L})\end{array}$ & $\begin{array}{l}\text { Ads } \\
\text { pH }\end{array}$ & rption C & $\begin{array}{r}\text { onditions } \\
t \text { (min) }\end{array}$ & $\begin{array}{c}\text { Adsorption } \\
\text { Capacity (mg/g) }\end{array}$ & Isotherms/Kinetics Model & References \\
\hline $\begin{array}{l}\mathrm{Fe}_{3} \mathrm{O}_{4} \text { magnetized } \\
\text { graphene oxide sponge }\end{array}$ & 400 & 0.625 & 3 & 308 & 2880 & 473 & $\begin{array}{c}\text { Temkin } \\
\text { model/pseudo-second-order model }\end{array}$ & [54] \\
\hline $\begin{array}{l}\text { Ferromanganese oxide } \\
\text { magnetic modified } \\
\text { biochar }\end{array}$ & 100 & 0.4 & 6 & 318 & 1440 & 101 & $\begin{array}{c}\text { Freundlich } \\
\text { model/pseudo-second-order model }\end{array}$ & [27] \\
\hline $\begin{array}{l}\text { Magnetic nano-scale } \\
\text { biosorbent }\end{array}$ & 10 & - & 6 & 303 & - & 56.0 & $\begin{array}{c}\text { Langmuir } \\
\text { model/pseudo-second-order model }\end{array}$ & [84] \\
\hline $\begin{array}{l}\mathrm{Fe}_{3} \mathrm{O}_{4} \text { magnetized } \\
\text { porous carbon }\end{array}$ & 30 & 1 & - & 303 & 7200 & - & $\begin{array}{c}\text { Freundlich } \\
\text { model/pseudo-second-order model }\end{array}$ & {$[67]$} \\
\hline $\begin{array}{l}\mathrm{MnFe}_{2} \mathrm{O}_{4} / \text { activated } \\
\text { carbon }\end{array}$ & 222 & 1 & 5 & 298 & - & 591 & $\begin{array}{l}\text { Freundlich } \\
\text { model/pseudo-second-order model }\end{array}$ & {$[66]$} \\
\hline $\begin{array}{c}\mathrm{Fe}_{3} \mathrm{O}_{4} \text { magnetized } \\
\text { chicken bone biochar } \\
\text { Nitrilotriacetic }\end{array}$ & 100 & 10 & 8 & 299 & 1440 & 93.2 & Freundlich model & {$[70]$} \\
\hline $\begin{array}{l}\text { acid-functionalized } \\
\mathrm{Fe}_{3} \mathrm{O}_{4} \text { magnetized } \\
\text { graphene oxide: }\end{array}$ & 50 & 0.192 & 4.0 & 298 & 1440 & 212 & $\begin{array}{c}\text { Langmuir } \\
\text { model/Pseudo-second-order model }\end{array}$ & [85] \\
\hline Magnetic hydrochar & 100 & 0.4 & - & 298 & 120 & 424 & $\begin{array}{c}\text { Langmuir } \\
\text { model/pseudo-second-order model }\end{array}$ & [86] \\
\hline $\begin{array}{l}\text { Thiourea-dioxide- } \\
\text { reduced } \mathrm{Fe}_{3} \mathrm{O}_{4} \\
\text { magnetized graphene } \\
\text { oxide }\end{array}$ & 10 & 70 & 4 & 313 & 1440 & 1233 & $\begin{array}{c}\text { Langmuir } \\
\text { model/pseudo-second-order model }\end{array}$ & [63] \\
\hline $\begin{array}{c}\text { Modified } \mathrm{Fe}_{3} \mathrm{O}_{4} \\
\text { magnetized } \\
\text { polyoxometalates } \\
\text { nanoparticle }\end{array}$ & 150 & 1 & 6.8 & 298 & 1440 & 133 & $\begin{array}{c}\text { Temkin } \\
\text { model/pseudo-second-order }\end{array}$ & [80] \\
\hline $\begin{array}{l}\mathrm{Fe}_{3} \mathrm{O}_{4} @ \mathrm{ZIF}-8 \\
\text { microspheres }\end{array}$ & - & 2.5 & - & 318 & 120 & 402 & $\begin{array}{c}\text { Langmuir } \\
\text { model/pseudo-second-order } \\
\text { kinetics model }\end{array}$ & [87] \\
\hline $\begin{array}{c}\text { Carbon } \\
\text { disulfide-modified } \\
\text { magnetic ion-imprinted } \\
\text { chitosan-Fe (III) }\end{array}$ & 100 & 0.5 & 8 & 298 & - & 516 & $\begin{array}{c}\text { Langmuir } \\
\text { model/pseudo-second-order model }\end{array}$ & [69] \\
\hline $\begin{array}{l}\Upsilon-\mathrm{Fe}_{2} \mathrm{O}_{3} / \text { nanoporous } \\
\text { activated carbon } \\
\text { composite }\end{array}$ & 150 & 0.1 & 4 & 323 & 270 & 60.6 & $\begin{array}{c}\text { Langmuir } \\
\text { model/pseudo-second-order model }\end{array}$ & [88] \\
\hline $\begin{array}{c}\mathrm{Fe}_{3} \mathrm{O}_{4} \text { magnetized } \\
\text { starch polyurethane }\end{array}$ & 20 & 2.5 & 6 & 298 & 240 & 16.4 & $\begin{array}{c}\text { Freundlich and Redlich-Peterson } \\
\text { isotherm models/pseudo-nth order } \\
\text { model }\end{array}$ & [76] \\
\hline $\mathrm{Fe}_{3} \mathrm{O}_{4}$ magnetized resin & 100 & 0.2 & - & 303 & - & - & $\begin{array}{l}\text { Freundlich } \\
\text { models/pseudo-second-order } \\
\text { model }\end{array}$ & [89] \\
\hline $\begin{array}{l}\mathrm{Fe}_{3} \mathrm{O}_{4} \text { magnetized } \\
\text { imprinted polymer } \\
\text { nanoshell }\end{array}$ & 88.89 & 0.5 & - & 298 & 720 & 55.0 & $\begin{array}{c}\text { Langmuir } \\
\text { model/pseudo-second-order model }\end{array}$ & [90] \\
\hline $\begin{array}{l}\mathrm{Fe}_{3} \mathrm{O}_{4} \text { magnetized } \\
\text { carbon composites }\end{array}$ & 80 & 2 & 6.8 & 303 & 1560 & 48.4 & $\begin{array}{c}\text { Freundlich } \\
\text { model/pseudo-second-order model }\end{array}$ & [68] \\
\hline $\begin{array}{l}\mathrm{Fe}_{3} \mathrm{O}_{4} \text { magnetized } \\
\text { polystyrene EDTA } \\
\text { microsphere }\end{array}$ & 40 & 3 & 6.3 & 303 & 720 & 166 & $\begin{array}{c}\text { Temkin } \\
\text { model/pseudo-second-order model }\end{array}$ & [91] \\
\hline $\begin{array}{l}\text { nanoparticles } \\
\text { magnetized } \\
\text { porous carbon }\end{array}$ & - & - & - & 318 & 720 & 397 & $\begin{array}{c}\text { Langmuir } \\
\text { model/pseudo-second-order model }\end{array}$ & [93] \\
\hline $\begin{array}{c}\mathrm{Fe}_{3} \mathrm{O}_{4} \text { magnetized } \\
\text { chitosan nanoparticles }\end{array}$ & 50 & 0.5 & 5.0 & 298 & 2880 & 78.1 & $\begin{array}{c}\text { Langmuir } \\
\text { model/pseudo-second-order model }\end{array}$ & [94] \\
\hline $\begin{array}{l}\text { La-modified } \\
\text { magnetic composite } \\
\text { Zr(VI)-based metal }\end{array}$ & 25 & 0.4 & 7 & 298 & 1440 & 146 & $\begin{array}{l}\text { Freundlich } \\
\text { model/pseudo-second-order model }\end{array}$ & [81] \\
\hline $\begin{array}{c}\text { organic framework } \\
\text { UiO-66- } \\
(\mathrm{COOH})_{2} / \mathrm{GO} \\
\text { composite }\end{array}$ & 100 & 0.5 & - & 298 & 2880 & 165 & $\begin{array}{c}\text { Langmuir } \\
\text { model/pseudo-secondary kinetic } \\
\text { model }\end{array}$ & [95] \\
\hline $\begin{array}{l}\text { Alkali-acid modifified } \\
\text { magnetic biochar }\end{array}$ & 200 & 1 & 7 & 318 & 1440 & 172.0 & $\begin{array}{l}\text { Langmuir-Freundlich model } \\
\text { /pseudo-second-order kinetics }\end{array}$ & [71] \\
\hline $\begin{array}{c}\text { Magnetic carbon-coated } \\
\text { cobalt oxide } \\
\text { nanoparticles (CoO@C) }\end{array}$ & 20 & 0.2 & 8 & - & 180 & 769 & $\begin{array}{l}\text { Temkin model } \\
\text { /pseudo-second order model }\end{array}$ & [72] \\
\hline $\begin{array}{l}\text { Nanocomposites of } \\
\text { Zero-va@Activated } \\
\text { carbon }\end{array}$ & 700 & 2.5 & 5 & 298 & 20 & 81.5 & $\begin{array}{l}\text { Langmuir model } \\
\text { /pseudo-second-order models. }\end{array}$ & [96] \\
\hline $\begin{array}{l}\text { Chitosan based } \\
\text { magnetic } \\
\text { nanocomposite }\end{array}$ & 60 & 0.1 & 7 & 298 & 180 & 215 & $\begin{array}{l}\text { Langmuir isotherm } \\
\text { /pseudosecond-order model }\end{array}$ & [46] \\
\hline
\end{tabular}


Table 2. Cont.

\begin{tabular}{|c|c|c|c|c|c|c|c|c|}
\hline Material & $\begin{array}{c}\text { Initial Concentration } \\
\text { of TC }(\mathrm{mg} / \mathrm{L})\end{array}$ & $\begin{array}{c}\text { Dosage } \\
(\mathrm{g} / \mathrm{L})\end{array}$ & $\begin{array}{l}\text { Ads } \\
\text { pH }\end{array}$ & $\begin{array}{l}\text { rption } \\
\text { T (K) }\end{array}$ & $\begin{array}{r}\text { nditions } \\
t \text { (min) }\end{array}$ & $\begin{array}{c}\text { Adsorption } \\
\text { Capacity (mg/g) }\end{array}$ & Isotherms/Kinetics Model & References \\
\hline Magnetic cellulose & 100 & 1 & 7 & 298 & 2880 & 44.9 & $\begin{array}{l}\text { Freundlich model } \\
\text { /Weber-Morris curve }\end{array}$ & [97] \\
\hline $\begin{array}{c}\text { Metal-organic } \\
\text { framework MIL-101(Cr) } \\
\text { loaded nano } \\
\text { zero-valent iron }\end{array}$ & 100 & 0.15 & - & 318 & 120 & 625 & $\begin{array}{l}\text { Langmuir model } \\
\text { /pseudosecond-order model }\end{array}$ & [98] \\
\hline $\begin{array}{l}\text { Magnetic Fe/porous } \\
\text { carbon hybrid } \\
\text { (MagFePC) }\end{array}$ & 140 & 0.05 & 7 & 298 & 1440 & 1301 & $\begin{array}{l}\text { Langmuir model } \\
\text { /pseudo-second-order model }\end{array}$ & [99] \\
\hline $\begin{array}{l}\text { Magnetic chicken bone } \\
\text { biochar (MCB) }\end{array}$ & 100 & 1 & 8 & 299 & 1440 & 98.9 & Freundlich isotherm & [70] \\
\hline $\begin{array}{c}\mathrm{Fe}_{3} \mathrm{O}_{4} \text {-g-CN@PEI- } \beta \\
\text {-CD NC }\end{array}$ & 265 & 0.04 & 9.2 & 320.1 & 20 & 833 & $\begin{array}{l}\text { Langmuir model } \\
\text { /pseudo-second-order model }\end{array}$ & [100] \\
\hline $\begin{array}{c}\text { Magnetic sludge } \\
\text { biochar (Fe/Zn-SBC) }\end{array}$ & 200 & 0.2 & - & 298 & 1440 & 145 & $\begin{array}{l}\text { Freundlich model } \\
\text { /pseudo-second-order model }\end{array}$ & [74] \\
\hline $\begin{array}{l}\mathrm{NiFe}_{2} \mathrm{O}_{4} \text {-COF-chitosan- } \\
\text { terephthalaldehyde } \\
\text { nanocomposites fifilm } \\
\text { (NCCT) }\end{array}$ & 100 & 0.17 & 8 & - & 2400 & 389 & $\begin{array}{l}\text { Langmuir model } \\
\text { /pseudo-second-order model }\end{array}$ & [77] \\
\hline $\begin{array}{l}\text { Magnetic graphene } \\
\text { oxide/ZnO } \\
\text { nanocomposites (MZ) }\end{array}$ & 500 & 0.278 & 6 & - & 2400 & 1590 & $\begin{array}{l}\text { Freundlich model, } \\
\text { /pseudo-second-order } \\
\text { kinetics model }\end{array}$ & [65] \\
\hline $\begin{array}{l}\text { Fe-based metal-organic } \\
\text { frameworks }\end{array}$ & 100 & 4 & - & 298 & 1440 & 421 & $\begin{array}{l}\text { Freundlich model, } \\
\text { /pseudo-second-order } \\
\text { kinetics model }\end{array}$ & [79] \\
\hline
\end{tabular}

\subsection{Carbon-Based MCs}

\subsubsection{Graphene-Based MCs}

Graphene have gained considerable interests among many researchers due to high mechanical strength and chemical stability [24]. Moreover, Graphene is used as the most effective TC adsorbent due to its large surface area and tunable structure. Well-designed structural modifications of 2D graphene with three-dimensional (3D) substrates, such as metal ions and their oxides, bio-molecules, and hydrogels, offers outstanding platform for adsorption [101,102]. However, the original graphene is rarely used for TC, because it is not easy to react with organic matter $[103,104]$. Thus, researchers use chemical modification to enhance its adsorption capacity and promote its application [104]. Graphene oxide (GO) and reduced graphene oxide (rGO) are widely used derivatives of graphene, both in their pristine and composite form, in the fields of adsorption [24,105]. The adsorption effect of graphene oxide and reduced graphene oxide materials on TC will be specifically discussed in the section.

Magnetic graphene composites were prepared to facilitate the separation of graphene adsorbents. The researches have shown that magnetic graphene oxide sponge (MGOS) prepared by freeze-drying nano- $\mathrm{Fe}_{3} \mathrm{O}_{4}$ particles with well graphene oxide (GO) dispersion could effectively adsorb TC with adsorption capacity of $473.0 \mathrm{mg} \mathrm{g}^{-1}$, which was $50 \%$ higher than that of GO [54]. Moreover, the adsorption process was fast, and the $\mathrm{pH}$ and ionic strength had little effect on the adsorption. In addition, Li et al. [85] grafted nitrotriacetic acid onto magnetic graphene oxide (NDMGO) to adsorb TC from water and hydrogen bonds, amidation reaction, $\pi-\pi$, and cation $-\pi$ interaction were the adsorption mechanism between NDMGO and TC. Yang et al. [63] used magnetic graphene oxide (TDMGO) to remove TC from aqueous solution. The maximum adsorption capacity of TDMGO for TC was $1233.0 \mathrm{mg} \mathrm{g}^{-1}$ and the $\mathrm{pH}$ had little effect on adsorption. The pseudosecond-order kinetic model and Langmuir isotherm provided the better correlation for the experiment data. In addition, Qiao et al. [65] found that magnetic graphene oxide/zinc oxide nanocomposite (MZ) showed an excellent adsorption capacity for TC with adsorption capacity of $1590.3 \mathrm{mg} \mathrm{g}^{-1}$ and could be easily recycled. Electrostatic attraction, $\pi-\pi$ interaction, hydrogen bond, and cation exchange and complexation were the main modes of action. Shan et al. [106] 3D prepared reduced graphene oxide/nano- $\mathrm{Fe}_{3} \mathrm{O}_{4}$ hybrid hydrogel (3D-rGO/ $\mathrm{Fe}_{3} \mathrm{O}_{4}$ ) to remove TC from aqueous solution. The 3D-rGO/ $\mathrm{Fe}_{3} \mathrm{O}_{4}$ could effectively adsorb TC with adsorption capacity of $2044.4 \mathrm{mg} \mathrm{g}^{-1}$. Bao et al. [107] prepared manganese ferrite-rGO $\left(\mathrm{MnFe}_{2} \mathrm{O}_{4} / \mathrm{rGO}\right)$ composite for TC removal with adsorption ca- 
pacity of $1131.0 \mathrm{mg} \mathrm{g}^{-1}$. The growth of $\mathrm{MnFe}_{2} \mathrm{O}_{4}$ played an important role to enhance TC removal.

\subsubsection{Biochar-Based MCs}

Biochar was used for environmental remediation and received extensive attention in regards to the removal of organic pollutants in water $[58,108,109]$. To achieve an easy separation in application, magnetic biochar has been extensively studied. Shao et al. [66] found that $\mathrm{MnFe}_{2} \mathrm{O}_{4} /$ activated carbon magnetic composites had excellent performance for TC in aqueous solution. The results indicated that the adsorption capacity was $261.8 \mathrm{mg} \mathrm{g}^{-1}$, and accorded the pseudo-second-order kinetic model. Song et al. [96] prepared hybrid nanocomposites of zero-valent iron loaded the activated carbon (ZVI@ACCS) to adsorb TC and the synergistic interactions of the electrostatic attraction, the bridging complexation, and the surface complexation could be used to explain the mechanism of adsorption. The biochar-supported iron-copper bimetallic composites (BC-FeCu) were successfully prepared by Liu et al. [73]. The adsorption and degradation of TC by BC-FeCu accounted for $26.1 \%$ and $73.9 \%$ of the total removal rate, respectively. Yang et al. [72] prepared magnetic carbon-coated cobalt oxide nanoparticles (CoO@C) to remove TC with an adsorption capacity of $769.4 \mathrm{mg} \mathrm{g}^{-1}$. Zeta-potential and X-ray Photoelectron Spectroscopy analysis showed that there was a strong electrostatic interaction between the positive charge on the surface of CoO@C and TC.

The texture of biochar would affect the adsorption capacity of TC on the MCs. Dai et al. [47] modified rice straw biochar by an alkali-acid combined magnetization method. The adsorption capacity could reach $98.3 \mathrm{mg} \mathrm{g}^{-1}$, and the main adsorption mechanisms were the hydrogen bonding and pore filling effect. Ma et al. [74] used municipal sludge biochar to synthesis magnetic sludge biochar (Fe/Zn-SBC) for removing TC. The results showed that the maximum adsorption capacity of $\mathrm{Fe} / \mathrm{Zn}-\mathrm{SBC}$ was $145.0 \mathrm{mg} \mathrm{g}^{-1}$ and the adsorption process was dominated by pore filling, complexation of oxygen-containing groups, $\pi-\pi$ conjugation, and hydrogen bonding. Rattanachueskul et al. [68] transformed bagasse into a new type of magnetic carbon composite and the maximum adsorption capacity was $48.4 \mathrm{mg} \mathrm{g}^{-1}$. The adsorption of TC by magnetic adsorbents was mainly realized by the interaction between hydrogen bond and TC.

\subsection{Polymer-Based MCs}

\subsubsection{Chitosan-Based MCs}

Polymer nanocomposites have been used to remove organic and inorganic pollutants from aqueous solutions [59]. Among all kinds of natural polymers, chitosan is the second most abundant natural biopolymer [69]. Chitosan has been considered as a promising adsorbent because of the existence of amino and hydroxyl groups. Chen et al. [69] reported magnetic ion imprinted chitosan-Fe (III) composite have good adsorption capacity of 516.3 $\mathrm{mg} \mathrm{g}^{-1}$. Li et al. [77] found that $\mathrm{NiFe}_{2} \mathrm{O}_{4}$-COF-chitosan-terephthalaldehyde nanocomposite film (NCCT) was an effective adsorbent for TC with the adsorption capacity of 388.5 $\mathrm{mg} \mathrm{g}^{-1}$. Complexation, cation exchange, electrostatic attraction, hydrogen bond, and $\pi-\pi$ interaction were the adsorption mechanisms of TC on NCCT. Ahamad et al. [28] used MCs prepared by chitosan, thiobarbituric acid, malondialdehyde, and $\mathrm{Fe}_{3} \mathrm{O}_{4}$ nanoparticles $\left(\mathrm{CTM} @ \mathrm{Fe}_{3} \mathrm{O}_{4}\right)$ to absorb TC with an adsorption capacity of $215.3 \mathrm{mg} \mathrm{g}^{-1}$. Langmuir model and the pseudo-second-order nonlinear model were the best models for fitting adsorption isotherms and adsorption kinetics.

\subsubsection{Resin-Based MCs}

Amino rich resin has attracted the attention of researchers in recent years due to its excellent adsorption capacity, good affinity, and chemical stability [2]. For example, Zhu et al. [75] prepared several magnetic polyamine resins (MMARs) for the removal of TC which showed that the specific surface area could reach up $1433.4 \mathrm{~m}^{2} \mathrm{~g}^{-1}$ and their adsorption capacity for TC reached $107.9 \mathrm{mg} \mathrm{g}^{-1}$. Wang et al. [5] observed that 
magnetic polyamine modified resin (MMAR-G) could be used to adsorb TC with the adsorption capacity of $46.2 \mathrm{mg} \mathrm{g}^{-1}$. In short, the behavior of TC adsorption on polymerbased magnetic composites generally followed the pseudo-second-order kinetic model and Langmuir model.

\subsection{Metal-Organic Framework (MOFs)}

MOF was a new type of highly ordered porous crystal hybrid materials with infinite skeleton structure, which can be self-assembled by multi-functional organic ligands and metal centers. Compared with traditional porous materials, MOFs have high porosity, high specific surface area, and rich active functional groups. They have attracted much attention because of their unique performance.

Xiao et al. [2] found that $\mathrm{NiCo} / \mathrm{Fe}_{3} \mathrm{O}_{4}$-MOF-74 magnetic composites had good enrichment and removal ability for $\mathrm{TC}$, and the removal rate reached $94.1 \%$ in $5 \mathrm{~min}$. The main interaction between adsorbents and TC was likely to have more available metal sites that could form stable metal ligands with TC. Zhang et al. [79] used three kinds of iron-based MOFs with different pore properties and open metal centers to remove tetracycline hydrochloride (TCH). Among them, MIL-101 (Fe) showed excellent adsorption performance for TCH with adsorption capacity of $420.6 \mathrm{mg} \mathrm{g}^{-1}$ due to much open metal centers and higher binding energy. In addition, the MOFs were uniformly and stably immobilized in the chitosan matrix [78]. The results showed that the maximum adsorption capacity could reach $495.0 \mathrm{mg} \mathrm{g}^{-1}$ and the pseudo-second-order model and Langmuir isotherm model could fit the adsorption process. The adsorption mechanisms included electrostatic interaction, $\pi-\pi$ stacking interaction, and hydrogen bond interaction. Gu et al. [99] also found that TC was removed efficiently by synergistic adsorption of carbon and iron. The adsorption capacity could reach up $1301.2 \mathrm{mg} \mathrm{g}^{-1}$ when the $\mathrm{pH}$ was about 7.

\subsection{Others}

In addition to the above three types of MCs, there are other types of MCs with unique properties and advantages in adsorbing TC. Mi et al. [81] introduced element lanthanum into magnetic substrate to improve its adsorption performance. The Langmuir model fitting results showed that the adsorption of TC on MCs could reach $145.9 \mathrm{mg} \mathrm{g}^{-1}$. Ou et al. [80] synthesized magnetic polyoxometalate adsorbents and found that there was a strong hydrogen bond between $\mathrm{NH}_{2}-\mathrm{Fe}_{3} \mathrm{O}_{4}$ and $\mathrm{CC} / \mathrm{POMNP}$, which kept the stability of the adsorbent. Wang et al. [83] studied the effect of nanometer titanium dioxide $\left(\mathrm{TiO}_{2}\right)$ on the adsorption and desorption of TC by magnetized kaolin (MK). The results showed that $\mathrm{TiO}_{2}$ nanoparticles increased the adsorption capacity of TC on MK by $2.02 \%$.

Generally, previous studies have demonstrated that MCs have exceptional performance in removing TC. To date, carbon-based MCs, polymer-based MCs, and MOFs have been mainly used to remove TC in aqueous solution. Carbon-based MCs and polymerbased MCs were the most widely used because of the porous structure and the huge specific surface area. Moreover, magnetic graphene and metal-modified magnetic biochar showed excellent performance in removing TC from aqueous solutions. Carbon-based MCs and graphene-based MCs could effectively remove TC by electrostatic, $\pi-\pi$ EDA, cation $-\pi$ bonding, hydrogen bonding, and hydrophobic interactions. Polymer-based MCs were mainly realized by complexation, cation exchange, electrostatic attraction, hydrogen bonding, and $\pi-\pi$ interaction to adsorb TC. The mechanisms of MOFs-MCs adsorbing TC mainly included electrostatic interaction, $\pi-\pi$ stacking interaction, and hydrogen bonding interaction because of their high porosity, large specific surface area, and abundant active functional groups.

\section{Magnetic Composites-Catalyzed Advanced Oxidation Processes (AOPs)}

In recent decades, AOPs have been considered as the most effective methods for organic pollutants degradation in water because the generated active oxygen species can destroy organic pollutants into innocuous or low-toxic small compounds [110,111]. 
Common AOPs include Fenton process, photocatalysis, microwave enhanced AOPs, electrochemical oxidation, and ultraviolet radiation.

MCs are widely used in photocatalysis, Fenton, and Fenton-like systems, not only in the degradation of antibiotics [112-114], but also in other organic pollutants, such as dye [115], pesticides [116], etc. With light activation or assistance by $\mathrm{H}_{2} \mathrm{O}_{2}$, persulfate, or other oxidants, $\mathrm{MCs}$ can generate active radicals such as $\mathrm{HO}_{2} \bullet, \mathrm{HO} \bullet, \mathrm{SO}_{4}{ }^{\bullet-}$ which induce a series of following reactions to decompose antibiotics $[67,108,117]$. In this section, the current development and application of MCs in degradation of TC through AOPs are systematically discussed. Specifically, the degradation of antibiotics by MCs could be divided into the following categories.

\subsection{Hydrogen Peroxide Based Advanced Oxidation Processes (H-AOPs)}

$\mathrm{H}-\mathrm{AOPs}$ is the most frequently used AOPs in TC disposal due to its environmental friendliness [117]. Simply, catalysts will activate hydrogen peroxide $\left(\mathrm{H}_{2} \mathrm{O}_{2}\right)$ under acidic conditions to generate highly reactive hydroxyl radicals. Various magnets or magnetic ferrites were employed to activate $\mathrm{H}_{2} \mathrm{O}_{2}$, such as $\mathrm{Fe}_{3} \mathrm{O}_{4}$ [112], $\mathrm{CuFe}_{2} \mathrm{O}_{4}$ [31] and $\mathrm{ZnFe}_{2} \mathrm{O}_{4}$ [118], etc. However, various magnets were of high density and less exposed active sites, which restrained the catalytic activity. Generally, the introduction of supports can overcome these limits and enhance efficiency of catalysts, and the simplified reactions in the photo-Fenton process were as follow [119]:

$$
\begin{gathered}
\mathrm{Fe}^{3+}+\mathrm{h} v \rightarrow \mathrm{Fe}^{2+}+\mathrm{HO} \bullet+\mathrm{H}^{+} \\
\mathrm{Fe}^{2+}+\mathrm{H}_{2} \mathrm{O}_{2} \rightarrow \mathrm{Fe}^{3+}+\mathrm{HO} \bullet+\mathrm{OH}^{-}
\end{gathered}
$$

Lai et al. [120] synthesized the $\mathrm{MnFe}_{2} \mathrm{O}_{4} /$ biochar composite to degrade TC in photoFenton system, the existence of biochar made the $\mathrm{MnFe}_{2} \mathrm{O}_{4}$ more stable and improved the degradation efficiency, and this catalyst could achieve more than $90 \%$ removal rate within a $\mathrm{pH}$ range of 3 to 9 . In the degradation process, TC was adsorbed onto the biochar surface, making it convenient for radicals to attack TC. Xin et al. [121] synthesized biochar modified $\mathrm{CuFeO}_{2}$ as Fenton-like catalyst to degrade TC. The $\mathrm{CuFeO}_{2} / \mathrm{BC}-1.0$ have a strong reusability, higher catalytic activity and high stability due to the synergistic effect of $\mathrm{Fe}^{3+} / \mathrm{Fe}^{2+}$ and $\mathrm{Cu}^{2+} / \mathrm{Cu}^{+}$redox cycles. Yu et al. [122] used $\mathrm{Fe}_{3} \mathrm{O}_{4}$-decorate hierarchical porous carbon skeleton $\left(\mathrm{Fe}_{3} \mathrm{O}_{4} @ \mathrm{MSC}\right)$ to degrade TC. The TC degradation efficiency reached up $99.2 \%$ after $40 \mathrm{~min}$. Kakavandi et al. [123] used $\mathrm{Fe}_{3} \mathrm{O}_{4}$ coated activated carbon (AC@ $\mathrm{Fe}_{3} \mathrm{O}_{4}$ ) as a peroxidase mimetic to degrade TC through Fenton-like catalytic progress. $\mathrm{AC} @ \mathrm{Fe}_{3} \mathrm{O}_{4}$ had high activity and degradation efficiency after five concessive cycles.

Biopolymers, such as chitosan and alginate, are recognized as efficient supporters for catalytic applications. For example, Li et al. [124] observed that magnetite nanoparticles were successfully embedded into chitosan beads and used for efficiently degrading TC. The results showed that about $96.0 \%$ of TC was degraded within $20 \mathrm{~min}$. The stable porous structure, abundant active sites, and possible synergistic effects between two components enhance the degradation performance of beads.

Recently, Fe-based MOFs have become a popular catalyst in which the Fe was proved to be a catalytically active center. Wu et al. [125] prepared Fe-based MOFs as Fenton-like catalysts for TC- $\mathrm{HCl}$ degradation. The result showed that the removal efficiency of TC-HCl and the apparent rate constant reached the maximum with adding $0.15 \mathrm{~g} \cdot \mathrm{L}^{-1}$ catalysts and $10 \mathrm{~mL} \cdot \mathrm{L}^{-1} \mathrm{H}_{2} \mathrm{O}_{2}$. Fe-based MOFs exhibited the best Photo-Fenton performance mainly attributed to its largest surface area and pore volume, and the most coordinately unsaturated iron sites.

As magnetic adsorbents or magnetic catalysts, iron-based materials have excellent properties due to electrical and magnetic properties [126,127]. Many studies have confirmed that iron-based materials were important component magnetic mineral composites. For example, Semeraro et al. [128] prepared a composite catalyst based on zinc oxide ( $\mathrm{ZnO})$ and iron oxide $\left(\gamma-\mathrm{Fe}_{2} \mathrm{O}_{3}\right)$ by a microwave-assisted aqueous solution method to degrade TC 
in aqueous solution. The results clearly demonstrated that the $\mathrm{ZnO} / \gamma-\mathrm{Fe}_{2} \mathrm{O}_{3}$ composite catalyst presented significant photocatalytic activity with the degradation efficiency of 88.5\%. Lian et al. [129] observed that magnetic palygorskite nanoparticles $\left(\mathrm{Pal}_{\mathrm{O}} \mathrm{Fe}_{3} \mathrm{O}_{4}\right)$ could efficiently degrade $\mathrm{TC}$ in a wide $\mathrm{pH}$ range of 3-7. In addition, Chen et al. [130] prepared $\mathrm{NiFe}_{2} \mathrm{O}_{4} / \mathrm{C}$ yolk-shell nanostructure using polyacrylic acid sodium salt as a template. Notably, the degradation rate of TC reached $97.2 \%$ in 60 min under visible light irradiation $(\lambda>400 \mathrm{~nm})$ with $\mathrm{NiFe}_{2} \mathrm{O}_{4} / \mathrm{C}$. Qin et al. [131] investigated the catalytic activity of magnetic core-shell $\mathrm{MnFe}_{2} \mathrm{O}_{4} @ \mathrm{C}$ and $\mathrm{MnFe}_{2} \mathrm{O}_{4} @ \mathrm{C}-\mathrm{NH}_{2}$ in the antibiotic degradation. Compared to $\mathrm{MnFe}_{2} \mathrm{O}_{4}, \mathrm{MnFe}_{2} \mathrm{O}_{4} @ \mathrm{C}$ and $\mathrm{MnFe}_{2} \mathrm{O}_{4} @ \mathrm{C}-\mathrm{NH}_{2}$ presented higher catalytic activity in the antibiotics and TOC removal. Mashayekh-Salehi et al. [132] found that pyrite from mine waste was an excellent mineral catalyst and $\bullet \mathrm{OH}$ was the main oxidizing species in a heterogeneous Fenton-like pyrite $/ \mathrm{H}_{2} \mathrm{O}_{2}$ process. More than $85 \%$ of TC was removed in $60 \mathrm{~min}$.

To sum up, different degradation mechanisms or processes during the MCs/Fenton systems were summarized as follows. Yu et al. [122] observed that the UV assisted heterogeneous Fenton-like process in $\mathrm{Fe}_{3} \mathrm{O}_{4} @ \mathrm{MSC}$ improved the cycle of $\mathrm{Fe}^{3+} / \mathrm{Fe}^{2+}$ and activated the interfacial catalytic site. The $\bullet \mathrm{OH}$ played an important role in the catalytic reaction. Li et al. [124] found that TC was adsorbed onto the beads' surface from the bulk solution through $\pi-\pi$ action between the benzenerings of TC and mesoporous $\mathrm{Fe}_{3} \mathrm{O}_{4}-\mathrm{Cs}$ beads. Moreover, the $\mathrm{Fe}_{3} \mathrm{O}_{4}$-C catalyst could catalyze $\mathrm{H}_{2} \mathrm{O}_{2}$ to form $\bullet \mathrm{OH}$ to attack TC through intramolecular electron transfer process. Wu et al. [125] reported that Fe-MOFs were effective Fenton-like catalysts and $\bullet \mathrm{OH}$ was the key reactive oxidative species. In addition, Nie et al. [133] found that $\bullet \mathrm{OH}$ and $\bullet \mathrm{O}_{2}{ }^{-} / \bullet \mathrm{HO}_{2}$ were involved in TC degradation by using the $\mathrm{Fe}_{3} \mathrm{O}_{4}-\mathrm{S} / \mathrm{H}_{2} \mathrm{O}_{2}$ system. Chen et al. [130] suggested that $\mathrm{NiFe}_{2} \mathrm{O}_{4} / \mathrm{C}$ was excited to generate electron-hole pairs in this conduction band and the valence band under visiblelight irradiation, which reacted with $\mathrm{Fe}^{3+}$ to form $\mathrm{Fe}^{2+}$ to directly reacted with $\mathrm{H}_{2} \mathrm{O}_{2}$ to produce $\bullet \mathrm{OH}$. Simultaneously, the holes of $\mathrm{NiFe}_{2} \mathrm{O}_{4} / \mathrm{C}$ were directly able to react with water or hydroxyl ions to generate hydroxyl radicals. Qin et al. [131] showed that the introduction of $-\mathrm{NH}_{2}$ enhanced the electron density of carbon shell and more electrons were transferred from carbon to the metal oxide, which enhanced the generation of $\bullet \mathrm{OH}$ radicals. Nie et al. [134] reported $\bullet \mathrm{OH}$ was the main active species in the entire reaction in ultrathin iron-cobalt oxide nanosheets $/ \mathrm{H}_{2} \mathrm{O}_{2}$ system. The main reactive species involved in H-AOPs for TC degradation are shown in Table 3.

Table 3. Synthesis methods for MCs and their leading reactive species during TC degradation.

\begin{tabular}{|c|c|c|c|c|c|c|}
\hline Magnetic Materials & Synthesis Techniques & $\begin{array}{l}\text { Leading Reactive } \\
\text { Species }\end{array}$ & $\begin{array}{l}\text { Removal } \\
\text { Rate (\%) }\end{array}$ & Quenchers & $\begin{array}{c}\text { Advanced Oxidation } \\
\text { Processes }\end{array}$ & References \\
\hline $\mathrm{Fe}_{3} \mathrm{O}_{4} @ \mathrm{MSC}$ & $\begin{array}{l}\text { Co-precipitation process } \\
\text { and a calcination process }\end{array}$ & $\bullet \mathrm{OH}$ & $99 \%$ & NA & H-AOPs & [135] \\
\hline $\begin{array}{c}\text { Biochar modified } \\
\mathrm{CuFeO}_{2}\left(\mathrm{CuFeO}_{2} / \mathrm{BC}\right)\end{array}$ & Hydrothermal method & $\bullet \mathrm{OH}$ & $88 \%$ & $\begin{array}{l}\text { Tert-butanol (TBA) and } \\
\text { benzoquinone (BO) }\end{array}$ & H-AOPs & [123] \\
\hline $\mathrm{Fe}_{3} \mathrm{O}_{4}-\mathrm{Cs}$ & Co-precipitation & $\bullet \mathrm{OH}$ & $96 \%$ & TBA, KI, BQ and DMPO & H-AOPs & [124] \\
\hline $\begin{array}{l}\text { Magnetic core-shell } \\
\mathrm{MnFe}_{2} \mathrm{O}_{4} @ \mathrm{C}\end{array}$ & Hydrothermal synthesis & $\bullet \mathrm{OH}$ & $64 \%$ & TBA and BQ & $\mathrm{H}$-AOPs & [131] \\
\hline Fe-MOFs & Solvothermal method & $\bullet \mathrm{OH}$ & $83 \%$ & NA & H-AOPs & [125] \\
\hline $\begin{array}{c}\text { Magnetic } \mathrm{NiFe}_{2} \mathrm{O}_{4} / \mathrm{C} \\
\text { yolk-shell } \\
\text { nanospheres }\end{array}$ & Calcination & $\bullet \mathrm{OH}$ and $\bullet \mathrm{O}_{2}{ }^{-}$ & $97 \%$ & $\begin{array}{c}\text { Isopropanol (IPA), } \\
\text { 4-hydroxy-TEMPO } \\
\text { (TEMPO), and } \\
\text { triethanolamine (TEOA) }\end{array}$ & H-AOPs & [130] \\
\hline $\mathrm{Fe}_{3} \mathrm{O}_{4}$ nanospheres & $\begin{array}{l}\text { One-pot solvothermal } \\
\text { method }\end{array}$ & $\bullet \mathrm{OH}, \bullet \mathrm{O}_{2}{ }^{-}$, and $\bullet \mathrm{HO}_{2}$ & $80 \%$ & TBA, KI, and BQ & H-AOPs & [133] \\
\hline $\begin{array}{c}\text { Magnetic palygorskite } \\
\text { nanoparticles } \\
\left(\mathrm{Pal} @ \mathrm{Fe}_{3} \mathrm{O}_{4}\right)\end{array}$ & Co-precipitation method & $\bullet \mathrm{OH}$ and $\bullet \mathrm{O}_{2}{ }^{-}$ & $73 \%$ & NA & $\mathrm{H}-\mathrm{AOPs}$ & [129] \\
\hline $\begin{array}{c}\mathrm{TiO}_{2} / \mathrm{Fe}_{3} \mathrm{O}_{4} \\
\text { hierarchical porous } \\
\text { composites }\end{array}$ & $\begin{array}{l}\text { High-temperature } \\
\text { calcination }\end{array}$ & $\bullet \mathrm{OH}$ and $\bullet \mathrm{O}_{2}{ }^{-}$ & $98 \%$ & TBA & $\mathrm{H}-\mathrm{AOPs}$ & [136] \\
\hline $\begin{array}{c}\text { Iron-cobalt oxide } \\
\text { nanosheets } \\
\text { (CoFe-ONSs) }\end{array}$ & $\begin{array}{l}\text { Surfactant-aided } \\
\text { co-reduction process }\end{array}$ & $\bullet \mathrm{OH}$ & $84 \%$ & TBA & H-AOPs & [134] \\
\hline $\begin{array}{c}\mathrm{FeNi}_{3} / \mathrm{SiO}_{2} / \mathrm{ZnO} \\
\text { magnetic } \\
\text { nano-composite }\end{array}$ & Solvothermal method & $\mathrm{h}^{+}, \bullet \mathrm{O}_{2}{ }^{-}$and $\bullet \mathrm{OH}$ & $100 \%$ & NA & H-AOPs & [137] \\
\hline $\begin{array}{c}\mathrm{MnFe}_{2} \mathrm{O}_{4} @ \mathrm{C}-\mathrm{NH}_{2} \\
\text { nanoparticles }\end{array}$ & Hydrothermal synthesis & $\bullet \mathrm{OH}$ & $64 \%$ & TBA and BQ & $\mathrm{H}-\mathrm{AOPs}$ & [131] \\
\hline $\begin{array}{c}\text { Sulfurized } \\
\text { oolitic hematite }\end{array}$ & Calcination & $\bullet \mathrm{OH}$ and $\bullet \mathrm{O}_{2}{ }^{-}$ & $90 \%$ & TBA and $\mathrm{p}-\mathrm{BQ}$ & H-AOPs & [138] \\
\hline
\end{tabular}


Table 3. Cont.

\begin{tabular}{|c|c|c|c|c|c|c|}
\hline Magnetic Materials & Synthesis Techniques & $\begin{array}{l}\text { Leading Reactive } \\
\text { Species }\end{array}$ & $\begin{array}{l}\text { Removal } \\
\text { Rate (\%) }\end{array}$ & Quenchers & $\begin{array}{c}\text { Advanced Oxidation } \\
\text { Processes }\end{array}$ & References \\
\hline Pyrite & & $\bullet \mathrm{OH}$ & $85 \%$ & NA & H-AOPs & [132] \\
\hline $\begin{array}{l}\text { Mn doped magnetic } \\
\text { biochar (MMBC) }\end{array}$ & $\begin{array}{l}\text { Co-precipitation and } \\
\text { high temperature } \\
\text { calcination }\end{array}$ & $\mathrm{SO}_{4}{ }^{\bullet-}$ and $\bullet \mathrm{OH}$ & $93 \%$ & $\begin{array}{c}\text { Methanol }(\mathrm{MeOH}), \text { TBA } \\
\text { and } \mathrm{BQ}\end{array}$ & S-AOPs & [139] \\
\hline $\begin{array}{l}\text { Magnetic rape straw } \\
\text { biochar (MRSB) }\end{array}$ & Pyrolysis & $\bullet \mathrm{O}_{2}^{-}, \bullet \mathrm{OH}$ and $\mathrm{SO}_{4}{ }^{\bullet-}$ & $86 \%$ & NA & S-AOPs & [140] \\
\hline FeS@BC & Physical ball milling & $\bullet \mathrm{OH}$ and $\mathrm{SO}_{4}^{\bullet-}$ & $87 \%$ & NA & S-AOPs & [108] \\
\hline $\begin{array}{l}\text { Biochar supported } \\
\text { nanosized iron } \\
(\mathrm{nFe}(0) / \mathrm{BC})\end{array}$ & $\begin{array}{l}\text { Chemical reduction } \\
\text { method }\end{array}$ & $\bullet \mathrm{OH}$ and $\mathrm{SO}_{4}^{\bullet-}$ & $98 \%$ & ethanol $(\mathrm{EtOH})$ and TBA & S-AOPs & [141] \\
\hline Fe@GBC & One-step method & $\bullet \mathrm{OH}$ and $\mathrm{SO}_{4}{ }^{\bullet-}$ & $100 \%$ & $\mathrm{MeOH}$ and TBA & S-AOPs & [142] \\
\hline $\begin{array}{c}\text { Nano Fe(0) } \\
\text { immobilized } \\
\text { mesoporous carbon }\end{array}$ & $\begin{array}{l}\text { Liquid-phase reduction } \\
\text { method }\end{array}$ & $\mathrm{SO}_{4}^{\bullet-}$ & $92 \%$ & $\mathrm{MeOH}$ and TBA & S-AOPs & [143] \\
\hline Fe-N-BC & Pyrolysis & $\begin{array}{c}\bullet \mathrm{O}_{2}^{-}, \bullet \mathrm{OH}, \mathrm{SO}_{4}{ }^{--} \text {and } \\
1 \mathrm{O}_{2}\end{array}$ & $98 \%$ & $\mathrm{MeOH}$ and TBA & S-AOPs & [144] \\
\hline MS-biochar & $\begin{array}{l}\text { One-pot synthetic } \\
\text { method }\end{array}$ & $\bullet \mathrm{OH}$ and $\mathrm{SO}_{4}^{\bullet-}$ & $89 \%$ & $\mathrm{MeOH}$ and TBA & S-AOPs & [145] \\
\hline Fe-SCG biochar & Pyrolysis & $\bullet \mathrm{OH}$ and $\mathrm{SO}_{4}^{\bullet-}$ & $96 \%$ & NA & S-AOPs & [9] \\
\hline Fe-MOFs & $\begin{array}{l}\text { Microwave-assisted } \\
\text { synthesis }\end{array}$ & $\bullet \mathrm{O}_{2}{ }^{-}$and $\mathrm{SO}_{4}{ }^{\bullet-}$ & $98 \%$ & $\mathrm{EtOH}, \mathrm{TBA}$ and $\mathrm{p}-\mathrm{BQ}$ & S-AOPs & [82] \\
\hline $\begin{array}{c}\text { Fe(II)-based } \\
\text { metal-organic } \\
\text { frameworks }\end{array}$ & Hydrothermal synthesis & $\bullet \mathrm{O}_{2}{ }^{-}, \bullet \mathrm{OH}$ and $\mathrm{SO}_{4}{ }^{\bullet-}$ & $97 \%$ & NA & S-AOPs & [146] \\
\hline $\begin{array}{c}\text { Magetite } \\
\text { nanoparticles (MNPs) } \\
\text { Magnetic }\end{array}$ & Hydrothermal methods & $\bullet \mathrm{OH}$ and $\mathrm{SO}_{4}^{\bullet-}$ & $74 \%$ & $\mathrm{MeOH}$ & S-AOPs & [113] \\
\hline $\begin{array}{l}\mathrm{CuO} / \mathrm{MnFe}_{2} \mathrm{O}_{4} \\
\text { nanocomposite }\end{array}$ & Co-precipitation & $\bullet \mathrm{OH}$ and $\mathrm{SO}_{4}^{\bullet-}$ & $91 \%$ & $\mathrm{MeOH}$ and TBA & S-AOPs & [147] \\
\hline $\begin{array}{c}\mathrm{CuFe}_{2} \mathrm{O}_{4} \text { magnetic } \\
\text { nano-particles }\end{array}$ & $\begin{array}{l}\text { Sol-gel combustion } \\
\text { method }\end{array}$ & $\bullet \mathrm{OH}$ and $\mathrm{SO}_{4}^{\bullet-}$ & $89 \%$ & $\mathrm{MeOH}$ & S-AOPs & {$[64]$} \\
\hline$\underset{\text { composite }}{\mathrm{C}_{3} \mathrm{~N}_{4} @ \mathrm{CoFe}_{2} \mathrm{O}_{4} / \mathrm{Fe}_{2} \mathrm{O}_{3}}$ & $\begin{array}{l}\text { Hydrothermal and } \\
\text { calcination method }\end{array}$ & $\bullet \mathrm{OH}$ and $\mathrm{SO}_{4}{ }^{\bullet-}$ & $100 \%$ & BQ, EDTA, TBA and IPA & S-AOPs & [148] \\
\hline $\begin{array}{c}\mathrm{MnFe}_{2} \mathrm{O}_{4} \\
\text { nanoparticles }\end{array}$ & Coprecipitation method & 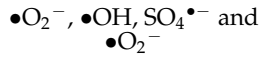 & $86 \%$ & $\begin{array}{c}\text { EtOH, TBA, p-BQ, and } \\
\text { L-His }\end{array}$ & S-AOPs & [149] \\
\hline $\begin{array}{c}\text { Magnetic } \mathrm{NixFe} 3-\mathrm{xO}_{4} \\
\mathrm{Agx}-\mathrm{BiFeO}_{3}\end{array}$ & $\begin{array}{c}\text { Calcination } \\
\text { Sol-gel method }\end{array}$ & $\begin{array}{l}\bullet \mathrm{OH} \text { and } \mathrm{SO}_{4}^{\bullet-} \\
\bullet \mathrm{OH} \text { and } \mathrm{SO}_{4}^{\bullet-}\end{array}$ & $\begin{array}{l}86 \% \\
91 \%\end{array}$ & $\begin{array}{l}\text { t-BuOH and } \mathrm{MeOH} \\
\text { t-BuOH and } \mathrm{MeOH}\end{array}$ & $\begin{array}{l}\text { S-AOPs } \\
\text { S-AOPs }\end{array}$ & $\begin{array}{l}{[117]} \\
{[150]}\end{array}$ \\
\hline $\begin{array}{c}\text { MIL-101(Fe)/ } / \mathrm{TiO}_{2} \\
\text { composite }\end{array}$ & Solvothermal method & $\bullet \mathrm{OH}$ & $90 \%$ & NA & S-AOPs & {$[151]$} \\
\hline Fe0@POCN/CQDs & Selfassembly method & $\mathrm{h}^{+}, \bullet \mathrm{O}_{2}^{-}, \cdot \bullet \mathrm{OH}$ and & $98 \%$ & $\begin{array}{c}\text { Sodium oxalate (SO), BQ } \\
\text { and IPA }\end{array}$ & S-AOPs & [152] \\
\hline $\mathrm{CNx} / \mathrm{Fe}_{3} \mathrm{O}_{4} / \mathrm{SS}$ & $\begin{array}{l}\text { Electro-polymerization } \\
\text { and Pyrolysis }\end{array}$ & $\bullet \mathrm{OH}$ and $\mathrm{SO}_{4}^{\bullet-}$ & $100 \%$ & NA & S-AOPs & [153] \\
\hline $\mathrm{Fe}_{3} \mathrm{O}_{4}$ nanoparticles & $\begin{array}{l}\text { Solvothermal method } \\
\text { Hydrothermal }\end{array}$ & $\bullet \mathrm{OH}$ and $\mathrm{SO}_{4}^{\bullet-}$ & $93 \%$ & NA & S-AOPs & [154] \\
\hline $\mathrm{Fe}_{3} \mathrm{O}_{4}$-NCS-x & $\begin{array}{l}\text { precarbonization and } \\
\text { pyrolysis }\end{array}$ & $\bullet \mathrm{OH}$ and $\bullet \mathrm{O}_{2}{ }^{-}$ & $97 \%$ & $\mathrm{MeOH}, \mathrm{TBA}$ and $\mathrm{p}-\mathrm{BQ}$ & S-AOPs & [111] \\
\hline MnFe-LDO-biochar & $\begin{array}{l}\text { Co-precipitation- } \\
\text { calcination } \\
\text { process }\end{array}$ & 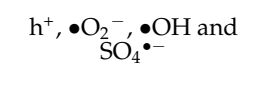 & $98 \%$ & $\mathrm{t}-\mathrm{BuOH}$ & photocatalysis & [155] \\
\hline $\begin{array}{c}\mathrm{TiO}_{2} \text { decorated on } \\
\text { magnetic activated } \\
\text { carbon (MAC@T) }\end{array}$ & 1 & $\bullet \mathrm{OH}$ and ${ }^{1} \mathrm{O}_{2}$ & $93 \%$ & $\begin{array}{l}\text { KI, TBA and sodium } \\
\text { azide (NaN3) }\end{array}$ & photocatalysis & [123] \\
\hline $\begin{array}{l}\text { Fe-based metal } \\
\text { organic frameworks } \\
\text { (MIL-88A) }\end{array}$ & Hydrothermal method & $\bullet \mathrm{O}_{2}{ }^{-}$and $\mathrm{SO}_{4}{ }^{\bullet-}$ & $100 \%$ & $\begin{array}{l}\text { TBA, EtOH, N2 and N2 } \\
\text { plus EtOH }\end{array}$ & photocatalysis & [156] \\
\hline $\mathrm{ZnO} / \gamma-\mathrm{Fe}_{2} \mathrm{O}_{3}$ & $\begin{array}{l}\text { Microwave assisted } \\
\text { aqueous solution } \\
\text { method }\end{array}$ & $\bullet \mathrm{O}_{2}{ }^{-}$and $\bullet \mathrm{OH}$ & $86 \%$ & $\begin{array}{l}\text { LAA, IPA and } \\
\text { EDTA-Na2 }\end{array}$ & photocatalysis & [128] \\
\hline $\begin{array}{c}\mathrm{ZnFe}_{2} \mathrm{O}_{4} \\
3 \mathrm{D} \mathrm{CoFe} 2 \mathrm{O}_{4} / \mathrm{N}-\mathrm{rGA}\end{array}$ & $\begin{array}{l}\text { Co-precipitation method } \\
\text { Hydrothermal method }\end{array}$ & $\begin{array}{l}\mathrm{h}^{+} \text {and } \bullet \mathrm{O}_{2}^{-} \\
\bullet \mathrm{OH} \text { and } \mathrm{SO}_{4}^{\bullet-}\end{array}$ & $\begin{array}{l}92 \% \\
94 \%\end{array}$ & $\begin{array}{c}\mathrm{t}-\mathrm{BuOH}, \mathrm{EDTA} \text { and } \mathrm{BQ} \\
\text { TBA }\end{array}$ & $\begin{array}{l}\text { photocatalysis } \\
\text { photocatalysis }\end{array}$ & $\begin{array}{l}{[157]} \\
{[158]}\end{array}$ \\
\hline $\begin{array}{c}\mathrm{FeNi}_{3} @ \mathrm{SiO}_{2} @ \mathrm{TiO}_{2} \\
\text { nanocomposite }\end{array}$ & Sol-gel method & $\bullet \mathrm{OH}$ & $100 \%$ & NA & photocatalysis & {$[53]$} \\
\hline
\end{tabular}

\subsection{Sulfate Radical Based Advanced Oxidation Processes (S-AOPS)}

S-AOPs generally aroused the interest of researchers since $\mathrm{SO}_{4}{ }^{\bullet-}\left(\mathrm{E}_{0}=2.6-3.1 \mathrm{~V}\right)$ had a comparable or even higher redox potential than $\bullet \mathrm{HO}\left(\mathrm{E}_{0}=1.8-2.7 \mathrm{~V}\right)$ at natural $\mathrm{pH}$ [159]. Further, $\mathrm{SO}_{4}{ }^{\bullet-}$ radical own longer half-life than $\bullet \mathrm{HO}$, and it can has better mass transfer ability and more stably contact with target contaminant [160]. The MCs can activate persulfate (PS) or peroxymonosulfate (PMS) to produce $\mathrm{SO}_{4}{ }^{\bullet-}$ and $\bullet \mathrm{OH}$ radicals which well further attacked antibiotics molecules to generate smaller intermediate product and eventually decompose TC to minerals or low-molecular-weight organics [37,48]. For example, Jiang et al. [143] found that the nano $\mathrm{Fe}^{0}$ was immobilized on $\mathrm{MC}$ to overcome the drawbacks of nano $\mathrm{Fe}^{0}$ for PS activation, including being easily aggregated and oxidized. The results showed that $\mathrm{SO}_{4}{ }^{--}$played a significant role for TC degradation in the nano $\mathrm{Fe}^{0} / \mathrm{MC}+\mathrm{PS}$ system. 
Zhou et al. [161] suggested that some functional structures of biochar (such as pore structure, oxygen-containing groups, and defects) could be beneficial to catalysis. The carboxy and hydroxyl on swine bone derived biochar (BBC) might enhance radical pathway, which can help to generate $\bullet \mathrm{OH}$ and $\mathrm{SO}_{4}{ }^{\bullet-}$. Likewise, Huang et al. [139] found that $\mathrm{Mn}$ doped magnetic biochar (MMBC) was highly conductive and electron transport existed in TC degradation. The removal efficiency of TC reached $93 \%$, which was much higher than that of the original BC (64\%). Huang et al. [140] also observed that magnetic rape straw biochar (MRSB) exhibited 13.2-fold higher reaction rate for activating PS than those of rape straw biochar (RSB) in the MRSB/PS system.

Wan et al. [82] found that Fe-based MOFs could enhance catalyst performance for PS to degrade organic pollutants. He et al. [151] used $\mathrm{TiO}_{2}$-based MOFs composite for TC degradation and the degradation rate was $90.15 \%$ in 5 min under xenon lamp irradiation. Lv et al. [162] used hydrothermal and calcination method to prepare g- $\mathrm{C}_{3} \mathrm{~N}_{4} @ \mathrm{CoFe}_{2} \mathrm{O}_{4} / \mathrm{Fe}_{2} \mathrm{O}_{3}$ composite. The results showed that MOF-derived $\mathrm{CoFe}_{2} \mathrm{O}_{4} / \mathrm{Fe}_{2} \mathrm{O}_{3}$ could remarkably enhance visible light absorption ability of $g-\mathrm{C}_{3} \mathrm{~N}_{4}$ and reduce band gap of $\mathrm{g}-\mathrm{C}_{3} \mathrm{~N}_{4}$. Significantly, TC of $99.7 \%$, BPA of $98.1 \%$, SMX of $94.8 \%$, DFC of $97.0 \%$, IBP of $96.1 \%$ and OFX of $96.5 \%$ could be removed within $80 \mathrm{~min}$.

$\mathrm{Li}$ et al. [48] investigated the TC degradation in the $\mathrm{Cu} / \mathrm{CuFe}_{2} \mathrm{O}_{4}$ activated PS system in which the $\mathrm{Cu}^{0}$ and in-situ generated $\mathrm{Cu}(\mathrm{I}), \mathrm{Cu}(\mathrm{II}), \mathrm{Cu}(\mathrm{III}), \mathrm{Fe}(\mathrm{II})$, and $\mathrm{Fe}(\mathrm{III})$ ions could activate persulfate to generate $\mathrm{SO}_{4}{ }^{\bullet-}$ and $\mathrm{OH} \bullet$. Ma et al. [147] used magnetic $\mathrm{CuO} / \mathrm{MnFe}_{2} \mathrm{O}_{4}$ nanocomposite as a heterogeneous catalyst to activate PS for levofloxacin (LVF) removal. The results revealed that the $\mathrm{CuO} / \mathrm{MnFe}_{2} \mathrm{O}_{4}$ showed higher catalytic performance than pure $\mathrm{CuO}$, pure $\mathrm{MnFe}_{2} \mathrm{O}_{4}$, and other fabricated $\mathrm{CuO} / \mathrm{MnFe}_{2} \mathrm{O}_{4}$ nanocomposites. Guan et al. [117] suggested that heterogeneous magnetic $\mathrm{Ni}_{\mathrm{x}} \mathrm{Fe}_{3-\mathrm{x}} \mathrm{O}_{4}$ catalysts could promoted TC degradation in $\mathrm{Ni}_{x} \mathrm{Fe}_{3-\mathrm{x}} \mathrm{O}_{4} / \mathrm{PS}$ system. The results showed that $\mathrm{Ni}_{0.6} \mathrm{Fe}_{2.4} \mathrm{O}_{4}$ presented superior catalytic activity performance and catalyze the PS to generate $\mathrm{SO}_{4}{ }^{\bullet-}$ and $\mathrm{HO} \bullet$ to efficiently degrade TC.

In general, $\mathrm{SO}_{4}{ }^{\bullet-}$ is generally produced by radiolysis, photolysis, pyrolysis, or chemical activation of PMS or PS. The reaction via metal ions and PMS/PS is primarily based on the electron transfer process between the metal ions and the oxidants. Herein, the following mechanisms were found during the TC degradation in MCs/S-AOPs system. Huang et al. [139] found surface oxygen-containing functional groups, and the defect structure of the material and the iron-manganese oxide were active reaction sites of $\mathrm{MMBC}$ to activate PS. Wan et al. [82] reported $\bullet \mathrm{O}_{2}{ }^{-}$and $\mathrm{SO}_{4}{ }^{\bullet-}$ played an important role in demineralizing the organic pollutants in the Fe-MOFs-D-7.5/PS system. Hu et al. [110] indicated that the transformation rates of $\mathrm{Fe}(\mathrm{II}) / \mathrm{Fe}(\mathrm{III})$ were the main factors to deter the catalytic efficiency of MNPs for PS in the PS/MNPs system. Guan et al. [117] found that high oxidative $\mathrm{SO}_{4}{ }^{\bullet-}$ and $\mathrm{HO} \bullet$ were the main radical species on TC degradation in the $\mathrm{Ni}_{0.6} \mathrm{Fe}_{2.4} \mathrm{O}_{4} /$ PS system. Tang et al. [149] suggested that the active radical contribution order could be concluded as follows: $\mathrm{SO}_{4}{ }^{\bullet-}>\bullet \mathrm{OH}>\bullet \mathrm{O}_{2}{ }^{-}>{ }^{1} \mathrm{O}_{2}$. The main reactive species involved during S-AOPs for degradation of TC are shown in Table 3.

\subsection{Photocatalysis}

Semiconductor can be activated by photon and inspired an electron from the valence band to the conductive band in the photocatalytic system, thus generate electron-hole pairs in the valence band, and the equation could be described as:

$$
\text { Semiconductor }+\mathrm{h} v \rightarrow \mathrm{e}^{-}+\mathrm{h}^{+}
$$

The $\mathrm{e}^{-}$and $\mathrm{h}^{+}$could further react with electron donors and acceptors on the surface of semiconductor to generate free radicals [163]. However, there were some limits occurring in the photocatalyst utilization, including low utilization of solar energy [164], high recombination rate of the photogenerated electron-holes [165], low stability, and difficult separation from water [26]. Therefore, the heterogeneous photocatalysts were developed to enhance the efficiency of pollutant degradation. 
Azalok et al. [155] prepared a high-efficiency layered double oxide-biochar hybrid (MnFe-LDO-biochar) catalyst to degrade TC in aqueous solution. The characterization results verified that MnFe-LDO-biochar possessed a specific surface area of $524.8 \mathrm{~m}^{2} \mathrm{~g}^{-1}$, appropriate bandgap ( $2.85 \mathrm{eV})$ and a mixture of interconnected pores. The MnFe-LDObiochar can effectively degrade TC with a removal rate of $98 \%$. Kakavandi et al. [123] found that $\mathrm{TiO}_{2}$ decorated magnetic activated carbon (MAC@T) coupled with US and UV irradiation could effectively remove TC in aqueous solution. At optimal conditions, over $93 \%$ TC was removed in $180 \mathrm{~min}$. Cao et al. [42] synthesized a plural photocatalyst consisting of graphene oxide, magnetite, and cerium-doped titania. The graphene oxide with large specific surface area can adsorb TC onto the catalyst surface, and the radicals activated by cerium-doped titania can rapidly react with adsorbed TC. Furthermore, the intermediates and photocatalytic route of TC degraded by this catalyst was analyzed by liquid chromatography-mass spectroscopy, and three routes were found.

Recently, Fe-based MOFs have also served as photocatalysts [79]. For example, Zhang et al. [156] used a hydrothermal method to synthesize Fe-based MOFs (MIL-88A) as a high-efficiency catalyst for degrading TCH under visible light irradiation. The $200 \mathrm{~mL}$ TC with a concentration of $100 \mathrm{mg} / \mathrm{L}$ could be entirely degraded and the degradation kinetics fitted well with the pseudo-second-order model. In addition, Wang et al. [165] used $\mathrm{Fe}_{3} \mathrm{O}_{4}$ to support $\mathrm{Bi}_{2} \mathrm{WO}_{6}$ at different composite ratio, and it was demonstrated that an appropriate amount of $\mathrm{Fe}_{3} \mathrm{O}_{4}$ could improve visible-light response and nanospheres morphology of the heterogeneous photocatalyst. Moreover, Semeraro et al. [128] investigated the photocatalytic activity of $\mathrm{ZnO} / \gamma-\mathrm{Fe}_{2} \mathrm{O}_{3}$ composite catalyst in the photocatalytic degradation of TC. The results clearly showed that the $\mathrm{ZnO} / \gamma-\mathrm{Fe}_{2} \mathrm{O}_{3}$ composite catalyst presented significant photocatalytic activity with degradation efficiency of $88.52 \%$. Moreover, $\mathrm{ZnO}$ was found to play the key role in the photocatalytic process assisted by $\gamma-\mathrm{Fe}_{2} \mathrm{O}_{3}$ which enhanced the TC degradation efficiency by $20 \%$.

Nasseh et al. [137] prepared magnetically separable $\mathrm{FeNi}_{3} / \mathrm{SiO}_{2} / \mathrm{ZnO}$ nano-composite to degrade TC under simulated sunlight. Khodadadi et al. [53] prepared $\mathrm{FeNi}_{3} @ \mathrm{SiO}_{2} @ \mathrm{TiO}_{2}$ nanocomposite to remove TC by photo-catalytic degradation in simulated wastewater. The results showed that $\mathrm{ZnFe}_{2} \mathrm{O}_{4}$ catalyst had both microwave-catalytic and visible-light photocatalytic activities and $91.6 \%$ of TCH degradation was obtained in the MW/MEDL/ $\mathrm{ZnFe}_{2} \mathrm{O}_{4}$ system in $4 \mathrm{~min}$.

Among many photocatalytic materials, $\mathrm{g}-\mathrm{C}_{3} \mathrm{~N}_{4}$, as a typical metal-free organic semiconductor photocatalyst, has attracted much attention in the field of photocatalysis due to convenient synthesis, nontoxicity, low-cost, and suitable band gap. Sun et al. [34] found that the N-deficient g- $\mathrm{C}_{3} \mathrm{~N}_{4}(\mathrm{CNx}) / \mathrm{PS}$ system displayed a high efficiency in the photocatalytic process of TC degradation. Wang et al. [166] reported the $\mathrm{C}_{3} \mathrm{~N}_{4} @ \mathrm{MnFe}_{2} \mathrm{O}_{4}-\mathrm{G}$ composites showed a superior catalytic activity with $94.5 \%$ removal of metronidazole that was almost 3.5 times as high as that of the pure $\mathrm{g}-\mathrm{C}_{3} \mathrm{~N}_{4}$ which could be attributed to the synergistic promoting effect of the favorable adsorption.

Overall, MCs were efficient photocatalysts and could effectively remove TC in aqueous solution under photocatalytic process. The reactive oxygen species such as $\bullet \mathrm{O}_{2}{ }^{-}$, - $\mathrm{OH}$, and $\mathrm{H}_{2} \mathrm{O}_{2}$ played important role to degrade TC, because the reactive oxygen species attacked TC molecules and converted it into less-toxic intermediates or completely degraded into the $\mathrm{CO}_{2}$ and $\mathrm{H}_{2} \mathrm{O}$ [57]. The following mechanisms existed in the degradation of TC by MCs during the photocatalytic process. Azalok et al. [155] found that the TC photodegradation mechanism was induced mainly by $\bullet \mathrm{OH}$ and $\mathrm{SO}_{4}{ }^{\bullet-}$ while $\mathrm{h}^{+}$and $-\mathrm{O}_{2}{ }^{-}$contributed partly to the TC decomposition in the MnFe-LDO-biochar system. Kakavandi et al. [123] observed that $\bullet \mathrm{OH}$ and ${ }^{1} \mathrm{O}_{2}$ were main oxygen species in (MAC@T) coupling with the US/UV irradiation system. In addition, Pang et al. [157] suggested that $\mathrm{h}^{+}$was the main active species for TCH degradation and little $\bullet \mathrm{O}_{2}{ }^{-}$active species generated in MW/MEDL/ZnFe $2 \mathrm{O}_{4}$ system. Wang et al. [166] reported that the $\mathrm{h}^{+}, \bullet \mathrm{O}_{2}{ }^{-}$, $\mathrm{SO}_{4}{ }^{\bullet-}$, and $\bullet \mathrm{OH}$ were responsible for the TC decomposition in $\mathrm{C}_{3} \mathrm{~N}_{4} @ \mathrm{MnFe}_{2} \mathrm{O}_{4}-\mathrm{G}$ system. 
The main reactive species involved during the photoatalytic removal of TC on different reaction systems are shown in Table 3.

AOPs could efficiently degrade tetracycline through active free radicals attacking the chain structure of TC. In this section, the application of MCs on the removal of TC via AOPs is fully presented. $\bullet \mathrm{O}_{2}{ }^{-}, \bullet \mathrm{OH}$, and $\mathrm{SO}_{4}{ }^{\bullet-}$ played important roles to degrade TC during AOPs. Moreover, the MCs could degrade TC through Fenton, Fenton-like, photo-Fenton, photocatalysis processes, and sulfate-based AOPs, and their performances were superior to the homogenous catalyst due to the high stability and synergistic effect between components. For $\mathrm{H}$-AOPs, $\bullet \mathrm{OH}$ was the most important active species and $\bullet \mathrm{OH}$ production rate determines the degradation efficiency of TC in the system. For S-AOPs, the system had strong stability and tetracycline degradation efficiency, because the system can produce a variety of active species. For photocatalysis, the organic-inorganic composite magnetic photocatalyst has a smaller band gap, and thus has a stronger catalytic ability, because it improves the utilization rate of the light source.

\section{Synergistic Effects between MC Components for Degrading TC}

In many cases, the combination of two components could create synergistic effect to improve the degradation efficiency of TC because certain materials can prevent magnets from agglomeration. Lai et al. [120] fabricated a $\mathrm{MnFe}_{2} \mathrm{O}_{4} /$ biochar composite, in which the biochar was fictionalized to prevent magnets from the aggregation proven by SEM. Likewise, Pi et al. [167] synthesized $\mathrm{Fe}_{3} \mathrm{O}_{4}$ magnetized biochar, and the SEM images showed that the $\mathrm{Fe}_{3} \mathrm{O}_{4}$ was uniformly coated on the biochar surface. Li et al. [124] observed that chitosan biopolymer serving as support can prevent the agglomeration of $\mathrm{Fe}_{3} \mathrm{O}_{4} \mathrm{NPs}$ and the $\mathrm{H}_{2} \mathrm{O}_{2}$ could be activated by the strong synergistic effect between Fe-based groups and carbon matrix, thereby increasing the degradation efficiency of TC. Huang et al. [139] found that MRSB could greatly accelerate generation of $\mathrm{SO}_{4}{ }^{\bullet-}, \bullet \mathrm{OH}$, and $\bullet \mathrm{O}_{2}{ }^{-}$to enhance the TC degradation efficiency. Moreover, Lv et al. [162] reported the introduction of MOFs-derived $\mathrm{CoFe}_{2} \mathrm{O}_{4} / \mathrm{Fe}_{2} \mathrm{O}_{3}$ provided a new approach for generating radical species, and the $\mathrm{k}$ value of $\mathrm{g}-\mathrm{C}_{3} \mathrm{~N}_{4} @ \mathrm{CoFe} \mathrm{O}_{4} / \mathrm{Fe}_{2} \mathrm{O}_{3}$ was the highest $(0.0524$ $\mathrm{min}^{-1}$ ), which was nearly 26.2 times as high as that of $\mathrm{g}-\mathrm{C}_{3} \mathrm{~N}_{4}$. These results fully indicated that MOFs-derived $\mathrm{CoFe}_{2} \mathrm{O}_{4} / \mathrm{Fe}_{2} \mathrm{O}_{3}$ could greatly enhance photocatalytic efficiency of g- $\mathrm{C}_{3} \mathrm{~N}_{4}$. Furthermore, the surface interaction of components can accelerate the separation of photogenerated electron-hole pairs, thus enhancing catalytic activity. For instance, Zhu et al. [168] synthesized a nanoreactor (MS@FCN) whose core was $\mathrm{Fe}_{3} \mathrm{O}_{4}$ magnetized graphitic carbon nitride $\left(\mathrm{Fe}_{3} \mathrm{O}_{4} / \mathrm{g}-\mathrm{C}_{3} \mathrm{~N}_{4}\right)$ and a shell of mesoporous silica. The prominent electrical conductivity of $\mathrm{Fe}_{3} \mathrm{O}_{4}$ restrained the recombination of electron-hole in the graphitic carbon nitride, which befitted the charge separation and lengthened the life of the photocarrier, thus facilitating the generation of radicals, while the mesoporous silica shell provided a big surface area and refractive condition that enhanced the photocatalytic activity. In addition, $\mathrm{He}$ et al. [151] observed that $\mathrm{TiO}_{2}$ introduced in the composite played an important role in the degradation process, in which $\mathrm{TiO}_{2}$ had a synergistic effect with $\mathrm{Fe}^{3+}$ to generate $\mathrm{Fe}^{2+}, \mathrm{Ti}^{3+}$ and radicals $\mathrm{Fe}^{2+}$ reacted with $\mathrm{PS}$ to produce $\mathrm{Fe}^{3+}$ and a number of $\bullet \mathrm{OH}$ to degrade $\mathrm{TC}$ in $\mathrm{TiO}_{2}$-based metal-organic frameworks system. Pu et al. [146] found surface-bound Fe(II) acted as the main active site to provide electrons for PS or dissolved oxygen and effectively activate PS.

To sum up, the magnetic heterogeneous catalysts could bring the following advantages for the degradation of TC via AOPs: They (1) facilitated the separation and enhanced the stability of catalysts; (2) promoted the transformation of photogenerated charge carriers, depressed the recombination of electron-hole pairs, and prolonged the lifetime of the photogenerated holes, thus improved the catalytic ability; (3) prevented the aggregation of catalysts; (4) increased the production of free radicals; and (5) promoted the generation of free radicals as an intermediate. 


\section{Reusability of MCs}

For a catalyst, recyclability is an important characteristic, which relates to its cost of actual operation [169]. It is hard to restrain the decline in degradation performance because of the loss of quality, but thanks to the magnetic separation method, which lost less mass compared to filtration, sediment, and centrifugation [42], the magnetic catalysts showed satisfactory recyclability. Zhong et al. [43] synthesized a $\mathrm{ZnFe}_{2} \mathrm{O}_{4}$ magnetized $\mathrm{Bi}_{2} \mathrm{WO}_{6}$ to degrade $\mathrm{TCH}$ and observed that this material could still reach $81.52 \%$ removal efficiency after five cycles. Likewise, Guan et al. [117] tested the reusability of obtained magnetic $\mathrm{Ni}_{0.6} \mathrm{Fe}_{2.4} \mathrm{O}_{4}$ catalyst and discovered only a $3 \%$ decrease in the degradation rate after four times of reuse. Furthermore, the X-ray diffraction patterns of magnetic $\mathrm{Ni}_{0.6} \mathrm{Fe}_{2.4} \mathrm{O}_{4}$ catalyst before and after four times of reuse indicated that this material had high stability. Yu et al. [135] found that the UV assisted heterogeneous Fenton-like process in $\mathrm{Fe}_{3} \mathrm{O}_{4} @ \mathrm{MSC}$ improved the cycle of $\mathrm{Fe}^{3+} / \mathrm{Fe}^{2+}$ and activated the interfacial catalytic site, which eventually realized the enhancement of degradation and mineralization to TC. Wang et al. [138] reported that sulfured oolitic hematite ( $\mathrm{SOH}-600)$ exhibited an excellent recycling performance and a high catalytic efficiency $(>90 \%)$ after five cycles. Ren et al. [158] suggested that the degradation efficiency of TC was detected to be as high as $85 \%$ only within 10s and the degradation rate can remain above $90 \%$ after five cycles under the presence of $3 \mathrm{D} \mathrm{CoFe}_{2} \mathrm{O}_{4} / \mathrm{N}-\mathrm{rGA}$ and PMS.

\section{Recommendations}

Attention on applying MCs on TC removal in aqueous solutions has increased yearly due to the convenient separation of MCs from aqueous solution, and the stable, highly efficient removal performance. Although the MCs have been proven to be excellent heterogeneous catalysts, some research gaps still exist in the present research. Based on the literature, the following key perspectives should be addressed in the future: (1) The most common magnets used to synthesize $\mathrm{MCs}$ was $\mathrm{Fe}_{3} \mathrm{O}_{4}$, while other magnets, such as $\mathrm{CoFe}_{2} \mathrm{O}_{4}, \mathrm{NiFe}_{2} \mathrm{O}_{4}$, and $\mathrm{MgFe}_{2} \mathrm{O}_{4}$ with the better performance have not well been developed and utilized; (2) Less previous studies mentioned the cost of materials, but cost is a major obstacle to commercial applications; the cost analysis of materials should be better considered; (3) Further investigations should be carried out to attain the maximum possible efficiency and effectiveness regarding synthesis, application, and recycling of MCs; (4) The preparation of MCs is complicated and more attention should be paid to the green synthesis methodologies, e.g., ball milling method and microwave-assisted heating; (5) The $\mathrm{pH}$ of the reaction system has a great influence on the removal of TC from MCs. It is necessary to strengthen the adaptation range of the MCs to the $\mathrm{pH}$ of the system and improve the practical application ability of MCs; (6) Bi-pollutant, tri-pollutant, or multipollutant systems based on TC pollution system were more complicated and need more investigation; (7) MCs have a certain mass loss in the recycling process, and it is very necessary to develop novel recycling technologies; and (8) At present, the application of MCs was in the laboratory scale, and the governance of MCs in piratical engineering use requires more attention.

\section{Conclusions}

Previous studies have demonstrated that MCs have exceptional performance in removing TC. To date, carbon-based MCs, polymer-based MCs, and MOFs have been mainly used to remove TC in aqueous solution. Moreover, magnetic graphene and metal-modified magnetic biochar showed excellent performance in removing TC from aqueous solutions. The adsorption of TC on graphene-based MCs mainly accorded with the Langmuir model, while the adsorption of TC on biochar-based materials mainly conformed to the Freundlich model. In addition, Polymer-based MCs were generally suitable for the pseudo-secondorder kinetic model, which mainly accorded with Langmuir model. Complexation, cation exchange, electrostatic attraction, hydrogen bonding, and $\pi-\pi$ interaction played important roles to adsorb TC. 
AOPs are considered as an efficient, rapid, and environmentally-friendly approach for TC degradation. $\bullet \mathrm{O}_{2}{ }^{-}, \bullet \mathrm{OH}$, and $\mathrm{SO}_{4}{ }^{--}$were the main free radicals to degrade TC during AOPs. For H-AOPs, $\mathrm{MnFe}_{2} \mathrm{O}_{4} /$ biochar composite, Fe-MOFs, and $\mathrm{Fe}_{3} \mathrm{O}_{4}$-based materials had excellent catalytic ability in the photo-Fenton system. For S-AOPs, G$\mathrm{C}_{3} \mathrm{~N}_{4} @ \mathrm{CoFe}_{2} \mathrm{O}_{4} / \mathrm{Fe}_{2} \mathrm{O}_{3}$ composite, Fe-MOFs, and $\mathrm{Ni}_{\mathrm{x}} \mathrm{Fe}_{3-\mathrm{x}} \mathrm{O}_{4}$ catalysts had strong catalytic ability and the active radical contribution order could be concluded as follows: $\mathrm{SO}_{4}{ }^{\bullet-}>\bullet \mathrm{OH}>\bullet \mathrm{O}_{2}{ }^{-}>{ }^{1} \mathrm{O}_{2}$ in PS system. For photocatalysis, the g- $\mathrm{C}_{3} \mathrm{~N}_{4}\left(\mathrm{CN}_{\mathrm{x}}\right) /$ PS system had a strong catalytic ability for TC degradation.

Author Contributions: B.F., Y.T., J.W. and Y.P. collected the required materials and prepared the manuscript; B.Z. and Y.P. contributed the design and edition of the manuscript, B.Z., Y.P., B.F., C.G., X.G., C.Y. and S.C. reviewed and prepared the revised manuscript. All authors have read and agreed to the published version of the manuscript.

Funding: This research was funded by the Guizhou provincial Sci-Tech support project (No. 20182341, No. 20184008, No. 20193006-4, No. 20191452 and No. 20201Y073.

Institutional Review Board Statement: Not applicable.

Informed Consent Statement: Not applicable.

Data Availability Statement: The datasets generated during and/or analyzed during the current study are available from the corresponding author on reasonable request.

Acknowledgments: We gratefully acknowledge the financial support of the Guizhou provincial Sci-Tech support project, and we also greatly appreciated the anonymous reviewers for their valuable comments to improve the quality of this manuscript.

Conflicts of Interest: The authors declare no conflict of interest.

\section{References}

1. Xiang, W.; Wan, Y.; Zhang, X.; Tan, Z.; Xia, T.; Zheng, Y.; Gao, B. Adsorption of tetracycline hydrochloride onto ball-milled biochar: Governing factors and mechanisms. Chemosphere 2020, 255, 127057. [CrossRef] [PubMed]

2. Xiao, R.; Abdu, H.I.; Wei, L.; Wang, T.; Huo, S.; Chen, J.; Lu, X. Fabrication of magnetic trimetallic metal-organic frameworks for the rapid removal of tetracycline from water. Analyst 2020, 145, 2398-2404. [CrossRef] [PubMed]

3. Xu, Q.; Han, B.; Wang, H.; Wang, Q.; Zhang, W.; Wang, D. Effect of extracellular polymer substances on the tetracycline removal during coagulation process. Bioresour. Technol. 2020, 309, 123316. [CrossRef]

4. Debnath, B.; Majumdar, M.; Bhowmik, M.; Bhowmik, K.L.; Debnath, A.; Roy, D.N. The effective adsorption of tetracycline onto zirconia nanoparticles synthesized by novel microbial green technology. J. Environ. Manag. 2020, 261, 110235. [CrossRef] [PubMed]

5. Wang, W.; Zhu, Z.; Zhang, M.; Wang, S.; Qu, C. Synthesis of a novel magnetic multi-amine decorated resin for the adsorption of tetracycline and copper. J. Taiwan Inst. Chem. Eng. 2020, 106, 130-137. [CrossRef]

6. Gasparrini, A.J.; Markley, J.L.; Kumar, H.; Wang, B.; Fang, L.; Irum, S.; Symister, C.T.; Wallace, M.; Burnham, C.D.; Andleeb, S.; et al. Tetracycline-inactivating enzymes from environmental, human commensal, and pathogenic bacteria cause broad-spectrum tetracycline resistance. Commun. Biol. 2020, 3, 241. [CrossRef]

7. Alatalo, S.-M.; Daneshvar, E.; Kinnunen, N.; Meščeriakovas, A.; Thangaraj, S.K.; Jänis, J.; Tsang, D.C.W.; Bhatnagar, A.; Lähde, A. Mechanistic insight into efficient removal of tetracycline from water by Fe/graphene. Chem. Eng. J. 2019, 373, 821-830. [CrossRef]

8. Premarathna, K.S.D.; Rajapaksha, A.U.; Adassoriya, N.; Sarkar, B.; Sirimuthu, N.M.S.; Cooray, A.; Ok, Y.S.; Vithanage, M. Clay-biochar composites for sorptive removal of tetracycline antibiotic in aqueous media. J. Environ. Manag. 2019, 238, 315-322. [CrossRef] [PubMed]

9. Nguyen, V.-T.; Hung, C.-M.; Nguyen, T.-B.; Chang, J.-H.; Wang, T.-H.; Wu, C.-H.; Lin, Y.-L.; Chen, C.-W.; Dong, C.-D. Efficient Heterogeneous Activation of Persulfate by Iron-Modified Biochar for Removal of Antibiotic from Aqueous Solution: A Case Study of Tetracycline Removal. Catalysts 2019, 9, 49. [CrossRef]

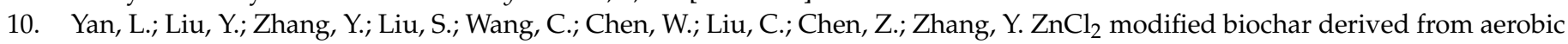
granular sludge for developed microporosity and enhanced adsorption to tetracycline. Bioresour. Technol. 2020, $297,122381$. [CrossRef] [PubMed]

11. $\mathrm{Wu}, \mathrm{S} . ; \mathrm{Hu}, \mathrm{H}$.; Lin, Y.; Zhang, J.; Hu, Y.H. Visible light photocatalytic degradation of tetracycline over $\mathrm{TiO}_{2}$. Chem. Eng. J. 2020, 382, 122842. [CrossRef]

12. Chen, C.Q.; Zheng, L.; Zhou, J.L.; Zhao, H. Persistence and risk of antibiotic residues and antibiotic resistance genes in major mariculture sites in Southeast China. Sci. Total Environ. 2017, 580, 1175-1184. [CrossRef] 
13. Wang, Z.; Chen, Q.; Zhang, J.; Dong, J.; Yan, H.; Chen, C.; Feng, R. Characterization and source identification of tetracycline antibiotics in the drinking water sources of the lower Yangtze River. J. Environ. Manag. 2019, 244, 13-22. [CrossRef] [PubMed]

14. Daghrir, R.; Drogui, P. Tetracycline antibiotics in the environment: A review. Environ. Chem. Lett. 2013, 11, 209-227. [CrossRef]

15. Ben, Y.; Fu, C.; Hu, M.; Liu, L.; Wong, M.H.; Zheng, C. Human health risk assessment of antibiotic resistance associated with antibiotic residues in the environment: A review. Environ. Res. 2019, 169, 483-493. [CrossRef] [PubMed]

16. Liu, X.; Zhang, G.; Liu, Y.; Lu, S.; Qin, P.; Guo, X.; Bi, B.; Wang, L.; Xi, B.; Wu, F.; et al. Occurrence and fate of antibiotics and antibiotic resistance genes in typical urban water of Beijing, China. Environ. Pollut. 2019, 246, 163-173. [CrossRef] [PubMed]

17. Xu, L.; Zhang, H.; Xiong, P.; Zhu, Q.; Liao, C.; Jiang, G. Occurrence, fate, and risk assessment of typical tetracycline antibiotics in the aquatic environment: A review. Sci. Total Environ. 2021, 753, 141975. [CrossRef]

18. Shao, S.; Hu, Y.; Cheng, J.; Chen, Y. Biodegradation mechanism of tetracycline (TEC) by strain Klebsiella sp. SQY5 as revealed through products analysis and genomics. Ecotoxicol. Environ. Saf. 2019, 185, 109676. [CrossRef]

19. Saitoh, T.; Shibata, K.; Hiraide, M. Rapid removal and photodegradation of tetracycline in water by surfactant-assisted coagulationsedimentation method. J. Environ. Chem. Eng. 2014, 2, 1852-1858. [CrossRef]

20. Kitazono, Y.; Ihara, I.; Yoshida, G.; Toyoda, K.; Umetsu, K. Selective degradation of tetracycline antibiotics present in raw milk by electrochemical method. J. Hazard. Mater. 2012, 243, 112-116. [CrossRef]

21. Palacio, D.A.; Leiton, L.M.; Urbano, B.F.; Rivas, B.L. Tetracycline removal by polyelectrolyte copolymers in conjunction with ultrafiltration membranes through liquid-phase polymer-based retention. Environ. Res. 2020, 182, 109014. [CrossRef]

22. Peng, Y.; Tang, H.; Yao, B.; Gao, X.; Yang, X.; Zhou, Y. Activation of peroxymonosulfate (PMS) by spinel ferrite and their composites in degradation of organic pollutants: A Review. Chem. Eng. J. 2021, 414, 128800. [CrossRef]

23. Acero, J.L.; Benitez, F.J.; Real, F.J.; Roldan, G. Kinetics of aqueous chlorination of some pharmaceuticals and their elimination from water matrices. Water Res. 2010, 44, 4158-4170. [CrossRef] [PubMed]

24. Minale, M.; Gu, Z.; Guadie, A.; Kabtamu, D.M.; Li, Y.; Wang, X. Application of graphene-based materials for removal of tetracyclines using adsorption and photocatalytic-degradation: A review. J. Environ. Manag. 2020, 276, 111310. [CrossRef] [PubMed]

25. De Bel, E.; Dewulf, J.; Witte, B.D.; Van Langenhove, H.; Janssen, C. Influence of pH on the sonolysis of ciprofloxacin: Biodegradability, ecotoxicity and antibiotic activity of its degradation products. Chemosphere 2009, 77, 291-295. [CrossRef]

26. Liu, M.; Hou, L.; Xi, B.; Li, Q.; Hu, X.; Yu, S. Magnetically separable Ag/AgCl-zero valent iron particles modified zeolite X heterogeneous photocatalysts for tetracycline degradation under visible light. Chem. Eng. J. 2016, 302, 475-484. [CrossRef]

27. Liang, J.; Fang, Y.; Luo, Y.; Zeng, G.; Deng, J.; Tan, X.; Tang, N.; Li, X.; He, X.; Feng, C.; et al. Magnetic nanoferromanganese oxides modified biochar derived from pine sawdust for adsorption of tetracycline hydrochloride. Environ. Sci. Pollut. Res. Int. 2019, 26, 5892-5903. [CrossRef]

28. Ahamad, T.; Naushad, M.; Al-Shahrani, T.; Al-Hokbany, N.; Alshehri, S.M. Preparation of chitosan based magnetic nanocomposite for tetracycline adsorption: Kinetic and thermodynamic studies. Int. J. Biol. Macromol. 2020, 147, 258-267. [CrossRef]

29. Turk Sekulic, M.; Boskovic, N.; Slavkovic, A.; Garunovic, J.; Kolakovic, S.; Pap, S. Surface functionalised adsorbent for emerging pharmaceutical removal: Adsorption performance and mechanisms. Process Saf. Environ. Prot. 2019, 125, 50-63. [CrossRef]

30. Zhou, J.; Ma, F.; Guo, H. Adsorption behavior of tetracycline from aqueous solution on ferroferric oxide nanoparticles assisted powdered activated carbon. Chem. Eng. J. 2020, 384, 123290. [CrossRef]

31. Chen, P.; Sun, F.; Wang, W.; Tan, F.; Wang, X.; Qiao, X. Facile one-pot fabrication of $\mathrm{ZnO}_{2}$ particles for the efficient Fenton-like degradation of tetracycline. J. Alloys Compd. 2020, 834, 155220. [CrossRef]

32. Emzhina, V.; Kuzin, E.; Babusenko, E.; Krutchinina, N. Photodegradation of tetracycline in presence of $\mathrm{H}_{2} \mathrm{O}_{2}$ and metal oxide based catalysts. J. Water Process. Eng. 2021, 39, 101696. [CrossRef]

33. Liu, D.; Li, X.; Ma, J.; Li, M.; Ren, F.; Zhou, L. Metal-organic framework modified pine needle-derived N, O-doped magnetic porous carbon embedded with Au nanoparticles for adsorption and catalytic degradation of tetracycline. J. Clean. Prod. 2021, 278, 123575. [CrossRef]

34. Sun, H.; Guo, F.; Pan, J.; Huang, W.; Wang, K.; Shi, W. One-pot thermal polymerization route to prepare N-deficient modified g- $\mathrm{C}_{3} \mathrm{~N}_{4}$ for the degradation of tetracycline by the synergistic effect of photocatalysis and persulfate-based advanced oxidation process. Chem. Eng. J. 2021, 406, 126844. [CrossRef]

35. Malesic-Eleftheriadou, N.; Evgenidou, E.; Kyzas, G.Z.; Bikiaris, D.N.; Lambropoulou, D.A. Removal of antibiotics in aqueous media by using new synthesized bio-based poly(ethylene terephthalate)- $\mathrm{TiO}_{2}$ photocatalysts. Chemosphere 2019, $234,746-755$. [CrossRef] [PubMed]

36. Singh, P.; Priya, B.; Shandilya, P.; Raizada, P.; Singh, N.; Pare, B.; Jonnalagadda, S.B. Photocatalytic mineralization of antibiotics using $60 \% \mathrm{WO}_{3} / \mathrm{BiOCl}$ stacked to graphene sand composite and chitosan. Arab. J. Chem. 2019, 12, 4627-4645. [CrossRef]

37. Jafari, A.J.; Kakavandi, B.; Jaafarzadeh, N.; Kalantary, R.R.; Ahmadi, M.; Babaei, A.A. Fenton-like catalytic oxidation of tetracycline by $\mathrm{AC} @ \mathrm{Fe}_{3} \mathrm{O}_{4}$ as a heterogeneous persulfate activator: Adsorption and degradation studies. J. Ind. Eng. Chem. 2017, 45, 323-333. [CrossRef]

38. Faisal, M.; Harraz, F.A.; Jalalah, M.; Alsaiari, M.; Al-Sayari, S.A.; Al-Assiri, M.S. Polythiophene doped ZnO nanostructures synthesized by modified sol-gel and oxidative polymerization for efficient photodegradation of methylene blue and gemifloxacin antibiotic. Mater. Today Commun. 2020, 24, 101048. [CrossRef] 
39. Wang, H.; Ye, Z.; Liu, C.; Li, J.; Zhou, M.; Guan, Q.; Lv, P.; Huo, P.; Yan, Y. Visible light driven Ag/Ag $\mathrm{PO}_{4} / \mathrm{AC}_{\mathrm{C}}$ photocatalyst with highly enhanced photodegradation of tetracycline antibiotics. Appl. Surf. Sci. 2015, 353, 391-399. [CrossRef]

40. Frindy, S.; Sillanpää, M. Synthesis and application of novel $\alpha-\mathrm{Fe}_{2} \mathrm{O}_{3}$ /graphene for visible-light enhanced photocatalytic degradation of RhB. Mater. Des. 2020, 188, 108461. [CrossRef]

41. Agarwal, S.; Tyagi, I.; Gupta, V.K.; Sohrabi, M.; Mohammadi, S.; Golikand, A.N.; Fakhri, A. Iron doped $\mathrm{SnO}_{2} / \mathrm{Co}_{3} \mathrm{O}_{4}$ nanocomposites synthesized by sol-gel and precipitation method for metronidazole antibiotic degradation. Mater. Sci. Eng. 2017, 70, 178-183. [CrossRef]

42. Cao, M.; Wang, P.; Ao, Y.; Wang, C.; Hou, J.; Qian, J. Visible light activated photocatalytic degradation of tetracycline by a magnetically separable composite photocatalyst: Graphene oxide/magnetite/cerium-doped titania. J. Colloid Interface Sci. 2016, 467, 129-139. [CrossRef] [PubMed]

43. Zhong, S.; Song, N.; Zhang, F.; Wang, Y.; Bai, L. Synthesis of $\mathrm{Bi}_{2} \mathrm{WO}_{6} / \mathrm{ZnFe}_{2} \mathrm{O}_{4}$ magnetic composite photocatalyst and degradation of tetracycline hydrochloride under visible light. J. Mater. Sci. 2017, 28, 6262-6271. [CrossRef]

44. Mehta, D.; Mazumdar, S.; Singh, S.K. Magnetic adsorbents for the treatment of water/wastewater-A review. J. Water Process Eng. 2015, 7, 244-265. [CrossRef]

45. Wang, H.; Xu, Y.; Jing, L.; Huang, S.; Zhao, Y.; He, M.; Xu, H.; Li, H. Novel magnetic $\mathrm{BaFe}_{12} \mathrm{O}_{19} /$ g- $\mathrm{C}_{3} \mathrm{~N}_{4}$ composites with enhanced thermocatalytic and photo-Fenton activity under visible-light. J. Alloy. Compd. 2017, 710, 510-518. [CrossRef]

46. Feng, Z.; Yuan, R.; Wang, F.; Chen, Z.; Zhou, B.; Chen, H. Preparation of magnetic biochar and its application in catalytic degradation of organic pollutants: A review. Sci. Total Environ. 2021, 765, 142673. [CrossRef] [PubMed]

47. Dai, J.; Meng, X.; Zhang, Y.; Huang, Y. Effects of modification and magnetization of rice straw derived biochar on adsorption of tetracycline from water. Bioresour. Technol. 2020, 311, 123455. [CrossRef]

48. Li, Z.; Guo, C.; Lyu, J.; Hu, Z.; Ge, M. Tetracycline degradation by persulfate activated with magnetic $\mathrm{Cu} / \mathrm{CuFe} 2 \mathrm{O}_{4}$ composite: Efficiency, stability, mechanism and degradation pathway. J. Hazard. Mater. 2019, 373, 85-96. [CrossRef] [PubMed]

49. Yi, Y.; Huang, Z.; Lu, B.; Xian, J.; Tsang, E.P.; Cheng, W.; Fang, J.; Fang, Z. Magnetic biochar for environmental remediation: A review. Bioresour. Technol. 2020, 298, 122468. [CrossRef]

50. Li, M.; Liu, H.; Chen, T.; Dong, C.; Sun, Y. Synthesis of magnetic biochar composites for enhanced uranium(VI) adsorption. Sci. Total Environ. 2019, 651, 1020-1028. [CrossRef]

51. Sherlala, A.I.A.; Raman, A.A.A.; Bello, M.M.; Buthiyappan, A. Adsorption of arsenic using chitosan magnetic graphene oxide nanocomposite. J. Environ. Manag. 2019, 246, 547-556. [CrossRef]

52. Tang, X.; Ni, L.; Han, J.; Wang, Y. Preparation and characterization of ternary magnetic g- $\mathrm{C}_{3} \mathrm{~N}_{4}$ composite photocatalysts for removal of tetracycline under visible light. Chin. J. Catal. 2017, 38, 447-457. [CrossRef]

53. Khodadadi, M.; Ehrampoush, M.H.; Ghaneian, M.T.; Allahresani, A.; Mahvi, A.H. Synthesis and characterizations of $\mathrm{FeNi}_{3} @ \mathrm{SiO}_{2} @ \mathrm{TiO}_{2}$ nanocomposite and its application in photo- catalytic degradation of tetracycline in simulated wastewater. J. Mol. Liq. 2018, 255, 224-232. [CrossRef]

54. Yu, B.; Bai, Y.; Ming, Z.; Yang, H.; Chen, L.; Hu, X.; Feng, S.; Yang, S.-T. Adsorption behaviors of tetracycline on magnetic graphene oxide sponge. Mater. Chem. Phys. 2017, 198, 283-290. [CrossRef]

55. Giakisikli, G.; Anthemidis, A.N. Magnetic materials as sorbents for metal/metalloid preconcentration and/or separation. A review. Anal. Chim. Acta 2013, 789, 1-16. [CrossRef] [PubMed]

56. Munoz, M.; de Pedro, Z.M.; Casas, J.A.; Rodriguez, J.J. Preparation of magnetite-based catalysts and their application in heterogeneous Fenton oxidation-A review. Appl. Catal. B 2015, 176-177, 249-265. [CrossRef]

57. Sharma, V.K.; Feng, M. Water depollution using metal-organic frameworks-catalyzed advanced oxidation processes: A review. J. Hazard. Mater. 2019, 372, 3-16. [CrossRef]

58. Li, X.; Wang, C.; Zhang, J.; Liu, J.; Liu, B.; Chen, G. Preparation and application of magnetic biochar in water treatment: A critical review. Sci. Total Environ. 2020, 711, 134847. [CrossRef] [PubMed]

59. Brião, G.d.V.; de Andrade, J.R.; da Silva, M.G.C.; Vieira, M.G.A. Removal of toxic metals from water using chitosan-based magnetic adsorbents. A review. Environ. Chem. Lett. 2020, 18, 1145-1168. [CrossRef]

60. Jacinto, M.J.; Ferreira, L.F.; Silva, V.C. Magnetic materials for photocatalytic applications-A review. J. Sol.-Gel. Sci. Technol. 2020, 96, 1-14. [CrossRef]

61. Bao, T.; Damtie, M.M.; Wei, W.; Phong Vo, H.N.; Nguyen, K.H.; Hosseinzadeh, A.; Cho, K.; Yu, Z.M.; Jin, J.; Wei, X.L.; et al. Simultaneous adsorption and degradation of bisphenol A on magnetic illite clay composite: Eco-friendly preparation, characterizations, and catalytic mechanism. J. Clean. Prod. 2021, 287, 125068. [CrossRef]

62. Bai, R.; Yan, W.; Xiao, Y.; Wang, S.; Tian, X.; Li, J.; Xiao, X.; Lu, X.; Zhao, F. Acceleration of peroxymonosulfate decomposition by a magnetic $\mathrm{MoS}_{2} / \mathrm{CuFe}_{2} \mathrm{O}_{4}$ heterogeneous catalyst for rapid degradation of fluoxetine. Chem. Eng. J. 2020, 397, 125501. [CrossRef]

63. Yang, Y.; Hu, X.; Zhao, Y.; Cui, L.; Huang, Z.; Long, J.; Xu, J.; Deng, J.; Wu, C.; Liao, W. Decontamination of tetracycline by thiourea-dioxide-reduced magnetic graphene oxide: Effects of $\mathrm{pH}$, ionic strength, and humic acid concentration. J. Colloid Interface Sci. 2017, 495, 68-77. [CrossRef]

64. Li, J.; Ren, Y.; Ji, F.; Lai, B. Heterogeneous catalytic oxidation for the degradation of $\mathrm{p}$-nitrophenol in aqueous solution by persulfate activated with $\mathrm{CuFe}_{2} \mathrm{O}_{4}$ magnetic nano-particles. Chem. Eng. J. 2017, 324, 63-73. [CrossRef]

65. Qiao, X.; Wang, C.; Niu, Y. N-Benzyl HMTA induced self-assembly of organic-inorganic hybrid materials for efficient photocatalytic degradation of tetracycline. J. Hazard. Mater. 2020, 391, 122121. [CrossRef] [PubMed] 
66. Shao, L.; Ren, Z.; Zhang, G.; Chen, L. Facile synthesis, characterization of a $\mathrm{MnFe}_{2} \mathrm{O}_{4}$ /activated carbon magnetic composite and its effectiveness in tetracycline removal. Mater. Chem. Phys. 2012, 135, 16-24. [CrossRef]

67. Zhu, X.; Liu, Y.; Qian, F.; Zhou, C.; Zhang, S.; Chen, J. Preparation of magnetic porous carbon from waste hydrochar by simultaneous activation and magnetization for tetracycline removal. Bioresour. Technol. 2014, 154, 209-214. [CrossRef]

68. Rattanachueskul, N.; Saning, A.; Kaowphong, S.; Chumha, N.; Chuenchom, L. Magnetic carbon composites with a hierarchical structure for adsorption of tetracycline, prepared from sugarcane bagasse via hydrothermal carbonization coupled with simple heat treatment process. Bioresour. Technol. 2017, 226, 164-172. [CrossRef] [PubMed]

69. Chen, A.; Shang, C.; Shao, J.; Lin, Y.; Luo, S.; Zhang, J.; Huang, H.; Lei, M.; Zeng, Q. Carbon disulfide-modified magnetic ion-imprinted chitosan-Fe(III): A novel adsorbent for simultaneous removal of tetracycline and cadmium. Carbohydr. Polym. 2017, 155, 19-27. [CrossRef]

70. Oladipo, A.A.; Ifebajo, A.O. Highly efficient magnetic chicken bone biochar for removal of tetracycline and fluorescent dye from wastewater: Two-stage adsorber analysis. J. Environ. Manag. 2018, 209, 9-16. [CrossRef] [PubMed]

71. Zhou, Y.; He, Y.; He, Y.; Liu, X.; Xu, B.; Yu, J.; Dai, C.; Huang, A.; Pang, Y.; Luo, L. Analyses of tetracycline adsorption on alkali-acid modified magnetic biochar: Site energy distribution consideration. Sci. Total Environ. 2019, 650, 2260-2266. [CrossRef]

72. Yang, G.; Gao, Q.; Yang, S.; Yin, S.; Cai, X.; Yu, X.; Zhang, S.; Fang, Y. Strong adsorption of tetracycline hydrochloride on magnetic carbon-coated cobalt oxide nanoparticles. Chemosphere 2020, 239, 124831. [CrossRef] [PubMed]

73. Liu, H.; Wang, C.; Wang, G. Photocatalytic Advanced Oxidation Processes for Water Treatment: Recent Advances and Perspective. Chem.-Asian J. 2020, 15, 3239-3253. [CrossRef]

74. Ma, Y.; Li, M.; Li, P.; Yang, L.; Wu, L.; Gao, F.; Qi, X.; Zhang, Z. Hydrothermal synthesis of magnetic sludge biochar for tetracycline and ciprofloxacin adsorptive removal. Bioresour. Technol. 2021, 319, 124199. [CrossRef]

75. Zhu, Z.; Zhang, M.; Wang, W.; Zhou, Q.; Liu, F. Efficient and synergistic removal of tetracycline and Cu(II) using novel magnetic multi-amine resins. Sci. Rep. 2018, 8, 4762. [CrossRef]

76. Okoli, C.P.; Ofomaja, A.E. Development of sustainable magnetic polyurethane polymer nanocomposite for abatement of tetracycline antibiotics aqueous pollution: Response surface methodology and adsorption dynamics. J. Clean. Prod. 2019, 217, 42-55. [CrossRef]

77. Li, Z.; Liu, Y.; Zou, S.; Lu, C.; Bai, H.; Mu, H.; Duan, J. Removal and adsorption mechanism of tetracycline and cefotaxime contaminants in water by $\mathrm{NiFe}_{2} \mathrm{O}_{4}$-COF-chitosan-terephthalaldehyde nanocomposites film. Chem. Eng. J. 2020, $382,123008$. [CrossRef]

78. Zhao, R.; Ma, T.; Zhao, S.; Rong, H.; Tian, Y.; Zhu, G. Uniform and stable immobilization of metal-organic frameworks into chitosan matrix for enhanced tetracycline removal from water. Chem. Eng. J. 2020, 382, 122893. [CrossRef]

79. Zhang, Z.; Chen, Y.; Wang, Z.; Hu, C.; Ma, D.; Chen, W.; Ao, T. Effective and structure-controlled adsorption of tetracycline hydrochloride from aqueous solution by using Fe-based metal-organic frameworks. Appl. Surf. Sci. 2021, 542, 148662. [CrossRef]

80. Ou, J.; Mei, M.; Xu, X. Magnetic adsorbent constructed from the loading of amino functionalized $\mathrm{Fe}_{3} \mathrm{O}_{4}$ on coordination complex modified polyoxometalates nanoparticle and its tetracycline adsorption removal property study. J. Solid State Chem. 2016, 238, 182-188. [CrossRef]

81. Mi, X.; Wang, M.; Zhou, F.; Chai, X.; Wang, W.; Zhang, F.; Meng, S.; Shang, Y.; Zhao, W.; Li, G. Preparation of La-modified magnetic composite for enhanced adsorptive removal of tetracycline. Environ. Sci. Pollut. Res. 2017, 24, 17127-17135. [CrossRef]

82. Wan, Y.; Wan, J.; Ma, Y.; Wang, Y.; Luo, T. Sustainable synthesis of modulated Fe-MOFs with enhanced catalyst performance for persulfate to degrade organic pollutants. Sci. Total Environ. 2020, 701, 134806. [CrossRef]

83. Wang, T.; Meng, Z.; Jiang, H.; Sun, X.; Jiang, L. Co-existing $\mathrm{TiO}_{2}$ nanoparticles influencing adsorption/desorption of tetracycline on magnetically modified kaolin. Chemosphere 2021, 263, 128106. [CrossRef]

84. Pi, S.; Li, A.; Wei, W.; Feng, L.; Zhang, G.; Chen, T.; Zhou, X.; Sun, H.; Ma, F. Synthesis of a novel magnetic nano-scale biosorbent using extracellular polymeric substances from Klebsiella sp. J1 for tetracycline adsorption. Bioresour. Technol. 2017, 245, 471-476. [CrossRef]

85. Li, M.; Liu, Y.; Zeng, G.; Liu, S.; Hu, X.; Shu, D.; Jiang, L.; Tan, X.; Cai, X.; Yan, Z. Tetracycline absorbed onto nitrilotriacetic acid-functionalized magnetic graphene oxide: Influencing factors and uptake mechanism. J. Colloid Interface Sci. 2017, 485, 269-279. [CrossRef] [PubMed]

86. Chen, S.-Q.; Chen, Y.-L.; Jiang, H. Slow Pyrolysis Magnetization of Hydrochar for Effective and Highly Stable Removal of Tetracycline from Aqueous Solution. Ind. Eng. Chem. Res. 2017, 56, 3059-3066. [CrossRef]

87. Liu, H.; Chen, L.; Ding, J. A core-shell magnetic metal organic framework of type $\mathrm{Fe}_{3} \mathrm{O}_{4} @ \mathrm{ZIF}-8$ for the extraction of tetracycline antibiotics from water samples followed by ultra-HPLC-MS analysis. Microchim. Acta 2017, 184, 4091-4098. [CrossRef]

88. Akkaya Sayğılı, G.; Sayğılı, H.; Koyuncu, F.; Güzel, F. Development and physicochemical characterization of a new magnetic nanocomposite as an economic antibiotic remover. Process Saf. Environ. Prot. 2015, 94, 441-451. [CrossRef]

89. Zhou, Q.; Li, Z.; Shuang, C.; Li, A.; Zhang, M.; Wang, M. Efficient removal of tetracycline by reusable magnetic microspheres with a high surface area. Chem. Eng. J. 2012, 210, 350-356. [CrossRef]

90. Dai, J.; Wei, X.; Cao, Z.; Zhou, Z.; Yu, P.; Pan, J.; Zou, T.; Li, C.; Yan, Y. Highly-controllable imprinted polymer nanoshell at the surface of magnetic halloysite nanotubes for selective recognition and rapid adsorption of tetracycline. RSC Adv. 2014, 4, 7967-7978. [CrossRef] 
91. Li, B.; Ma, J.; Zhou, L.; Qiu, Y. Magnetic microsphere to remove tetracycline from water: Adsorption, $\mathrm{H}_{2} \mathrm{O}_{2}$ oxidation and regeneration. Chem. Eng. J. 2017, 330, 191-201. [CrossRef]

92. Oladoja, N.A.; Adelagun, R.O.A.; Ahmad, A.L.; Unuabonah, E.I.; Bello, H.A. Preparation of magnetic, macro-reticulated cross-linked chitosan for tetracycline removal from aquatic systems. Colloids Surf. B 2014, 117, 51-59. [CrossRef] [PubMed]

93. Xie, A.; Cui, J.; Chen, Y.; Lang, J.; Li, C.; Yan, Y.; Dai, J. Simultaneous activation and magnetization toward facile preparation of auricularia-based magnetic porous carbon for efficient removal of tetracycline. J. Alloy. Compd. 2019, 784, 76-87. [CrossRef]

94. Raeiatbin, P.; Açıkel, Y. Removal of tetracycline by magnetic chitosan nanoparticles from medical wastewaters. Desalin. Water Treat 2017, 73, 380-388. [CrossRef]

95. Wang, Z.; Wang, H.; Zeng, Z.; Zeng, G.; Xu, P.; Xiao, R.; Huang, D.; Chen, X.; He, L.; Zhou, C.; et al. Metal-organic frameworks derived $\mathrm{Bi}_{2} \mathrm{O}_{2} \mathrm{CO}_{3}$ / porous carbon nitride: A nanosized Z-scheme systems with enhanced photocatalytic activity. Appl. Catal. $B$ 2020, 267, 118700. [CrossRef]

96. Song, Y.X.; Chen, S.; You, N.; Fan, H.T.; Sun, L.N. Nanocomposites of zero-valent Iron@Activated carbon derived from corn stalk for adsorptive removal of tetracycline antibiotics. Chemosphere 2020, 255, 126917. [CrossRef]

97. Sun, J.; Cui, L.; Gao, Y.; He, Y.; Liu, H.; Huang, Z. Environmental application of magnetic cellulose derived from Pennisetum sinese Roxb for efficient tetracycline removal. Carbohydr. Polym. 2021, 251, 117004. [CrossRef]

98. Hou, X.; Shi, J.; Wang, N.; Wen, Z.; Sun, M.; Qu, J.; Hu, Q. Removal of antibiotic tetracycline by metal-organic framework MIL-101(Cr) loaded nano zero-valent iron. J. Mol. Liq. 2020, 313, 113512. [CrossRef]

99. Gu, W.; Huang, X.; Tian, Y.; Cao, M.; Zhou, L.; Zhou, Y.; Lu, J.; Lei, J.; Zhou, Y.; Wang, L.; et al. High-efficiency adsorption of tetracycline by cooperation of carbon and iron in a magnetic Fe/porous carbon hybrid with effective Fenton regeneration. Appl. Surf. Sci. 2021, 538, 147813. [CrossRef]

100. Foroughi, M.; Ahmadi Azqhandi, M.H.; Kakhki, S. Bio-inspired, high, and fast adsorption of tetracycline from aqueous media using $\mathrm{Fe}_{3} \mathrm{O}_{4}$-g-CN@PEI- $\beta$-CD nanocomposite: Modeling by response surface methodology (RSM), boosted regression tree (BRT), and general regression neural network (GRNN). J. Hazard. Mater. 2020, 388, 121769. [CrossRef]

101. Kerkez-Kuyumcu, Ö.; Bayazit, Ş.S.; Salam, M.A. Antibiotic amoxicillin removal from aqueous solution using magnetically modified graphene nanoplatelets. J. Ind. Eng. Chem. 2016, 36, 198-205. [CrossRef]

102. Song, C.; Guo, B.-B.; Sun, X.-F.; Wang, S.-G.; Li, Y.-T. Enrichment and degradation of tetracycline using three-dimensional graphene $/ \mathrm{MnO}_{2}$ composites. Chem. Eng. J. 2019, 358, 1139-1146. [CrossRef]

103. Lingamdinne, L.P.; Koduru, J.R.; Karri, R.R. A comprehensive review of applications of magnetic graphene oxide based nanocomposites for sustainable water purification. J. Environ. Manag. 2019, 231, 622-634. [CrossRef]

104. Hegab, H.M.; Zou, L. Graphene oxide-assisted membranes: Fabrication and potential applications in desalination and water purification. J. Membr. Sci. 2015, 484, 95-106. [CrossRef]

105. Li, Z.; Qi, M.; Tu, C.; Wang, W.; Chen, J.; Wang, A.-J. Highly efficient removal of chlorotetracycline from aqueous solution using graphene oxide $/ \mathrm{TiO}_{2}$ composite: Properties and mechanism. Appl. Surf. Sci. 2017, 425, 765-775. [CrossRef]

106. Shan, D.; Deng, S.; Jiang, C.; Chen, Y.; Wang, B.; Wang, Y.; Huang, J.; Yu, G.; Wiesner, M.R. Hydrophilic and strengthened 3D reduced graphene oxide/nano- $\mathrm{Fe}_{3} \mathrm{O}_{4}$ hybrid hydrogel for enhanced adsorption and catalytic oxidation of typical pharmaceuticals. Environ. Sci. 2018, 5, 1650-1660. [CrossRef]

107. Bao, J.; Zhu, Y.; Yuan, S.; Wang, F.; Tang, H.; Bao, Z.; Zhou, H.; Chen, Y. Adsorption of Tetracycline with Reduced Graphene Oxide Decorated with $\mathrm{MnFe}_{2} \mathrm{O}_{4}$ Nanoparticles. Nanoscale Res. Lett. 2018, 13, 396. [CrossRef] [PubMed]

108. He, J.; Tang, J.; Zhang, Z.; Wang, L.; Liu, Q.; Liu, X. Magnetic ball-milled FeS@biochar as persulfate activator for degradation of tetracycline. Chem. Eng. J. 2021, 404, 126997. [CrossRef]

109. Liu, J.; Luo, K.; Li, X.; Yang, Q.; Wang, D.; Wu, Y.; Chen, Z.; Huang, X.; Pi, Z.; Du, W.; et al. The biochar-supported iron-copper bimetallic composite activating oxygen system for simultaneous adsorption and degradation of tetracycline. Chem. Eng. J. 2020, 402, 126039. [CrossRef]

110. Hu, L.; Ren, X.; Yang, M.; Guo, W. Facet-controlled activation of persulfate by magnetite nanoparticles for the degradation of tetracycline. Sep. Purif. Technol. 2021, 258, 118014. [CrossRef]

111. Yang, H.; Zhou, J.; Yang, E.; Li, H.; Wu, S.; Yang, W.; Wang, H. Magnetic $\mathrm{Fe}_{3} \mathrm{O}_{4}-\mathrm{N}$-doped carbon sphere composite for tetracycline degradation by enhancing catalytic activity for peroxymonosulfate: A dominant non-radical mechanism. Chemosphere 2021, 263, 128011. [CrossRef] [PubMed]

112. Jaafarzadeh, N.; Kakavandi, B.; Takdastan, A.; Kalantary, R.R.; Azizi, M.; Jorfi, S. Powder activated carbon $/ \mathrm{Fe}_{3} \mathrm{O}_{4}$ hybrid composite as a highly efficient heterogeneous catalyst for Fenton oxidation of tetracycline: Degradation mechanism and kinetic. RSC Adv. 2015, 5, 84718-84728. [CrossRef]

113. Rasheed, H.U.; Lv, X.; Zhang, S.; Wei, W.; Ullah, N.; Xie, J. Ternary MIL-100(Fe)@Fe $\mathrm{O}_{4} /$ CA magnetic nanophotocatalysts (MNPCs): Magnetically separable and Fenton-like degradation of tetracycline hydrochloride. Adv. Powder Technol. 2018, 29, 3305-3314. [CrossRef]

114. Wang, Q.; Wang, B.; Ma, Y.; Xing, S. Enhanced superoxide radical production for ofloxacin removal via persulfate activation with Cu-Fe oxide. Chem. Eng. J. 2018, 354, 473-480. [CrossRef]

115. Oladipo, A.A.; Ifebajo, A.O.; Gazi, M. Magnetic $\mathrm{LDH}-$ based $\mathrm{CoO}-\mathrm{NiFe}_{2} \mathrm{O}_{4}$ catalyst with enhanced performance and recyclability for efficient decolorization of azo dye via Fenton-like reactions. Appl. Catal. B 2019, 243, 243-252. [CrossRef] 
116. Blaskievicz, S.F.; Endo, W.G.; Zarbin, A.J.G.; Orth, E.S. Magnetic nanocatalysts derived from carbon nanotubes functionalized with imidazole: Towards pesticide degradation. Appl. Catal. B 2020, 264, 118496. [CrossRef]

117. Guan, R.; Yuan, X.; Wu, Z.; Wang, H.; Jiang, L.; Zhang, J.; Li, Y.; Zeng, G.; Mo, D. Accelerated tetracycline degradation by persulfate activated with heterogeneous magnetic $\mathrm{NixFe}_{3}-\mathrm{xO}_{4}$ catalysts. Chem. Eng. J. 2018, 350, 573-584. [CrossRef]

118. Shi, H.; Chen, X.; Liu, K.; Ding, X.; Liu, W.; Xu, M. Heterogeneous Fenton ferroferric oxide-reduced graphene oxide-based composite microjets for efficient organic dye degradation. J. Colloid Interface Sci. 2020, 572, 39-47. [CrossRef]

119. Clarizia, L.; Russo, D.; Di Somma, I.; Marotta, R.; Andreozzi, R. Homogeneous photo-Fenton processes at near neutral pH: A review. Appl. Catal. B 2017, 209, 358-371. [CrossRef]

120. Lai, C.; Huang, F.; Zeng, G.; Huang, D.; Qin, L.; Cheng, M.; Zhang, C.; Li, B.; Yi, H.; Liu, S.; et al. Fabrication of novel magnetic $\mathrm{MnFe}_{2} \mathrm{O}_{4}$ /bio-char composite and heterogeneous photo-Fenton degradation of tetracycline in near neutral pH. Chemosphere 2019, 224, 910-921. [CrossRef]

121. Xin, S.; Liu, G.; Ma, X.; Gong, J.; Ma, B.; Yan, Q.; Chen, Q.; Ma, D.; Zhang, G.; Gao, M.; et al. High efficiency heterogeneous Fenton-like catalyst biochar modified $\mathrm{CuFeO}_{2}$ for the degradation of tetracycline: Economical synthesis, catalytic performance and mechanism. Appl. Catal. B 2021, 280, 119386. [CrossRef]

122. Yu, X.; Lin, X.; Li, W.; Feng, W. Effective Removal of Tetracycline by Using Biochar Supported Fe $\mathrm{O}_{4}$ as a UV-Fenton Catalyst. Chem. Res. Chin. Univ. 2018, 35, 79-84. [CrossRef]

123. Kakavandi, B.; Bahari, N.; Rezaei Kalantary, R.; Dehghani Fard, E. Enhanced sono-photocatalysis of tetracycline antibiotic using $\mathrm{TiO}_{2}$ decorated on magnetic activated carbon (MAC@T) coupled with US and UV: A new hybrid system. Ultrason. Sonochemistry 2019, 55, 75-85. [CrossRef]

124. Li, X.; Cui, K.; Guo, Z.; Yang, T.; Cao, Y.; Xiang, Y.; Chen, H.; Xi, M. Heterogeneous Fenton-like degradation of tetracyclines using porous magnetic chitosan microspheres as an efficient catalyst compared with two preparation methods. Chem. Eng. J. 2020, 379, 122324. [CrossRef]

125. Wu, Q.; Yang, H.; Kang, L.; Gao, Z.; Ren, F. Fe-based metal-organic frameworks as Fenton-like catalysts for highly efficient degradation of tetracycline hydrochloride over a wide $\mathrm{pH}$ range: Acceleration of $\mathrm{Fe}(\mathrm{II}) / \mathrm{Fe}(\mathrm{III})$ cycle under visible light irradiation. Appl. Catal. B 2020, 263, 118282. [CrossRef]

126. Feng, L.; Li, X.; Chen, X.; Huang, Y.; Peng, K.; Huang, Y.; Yan, Y.; Chen, Y. Pig manure-derived nitrogen-doped mesoporous carbon for adsorption and catalytic oxidation of tetracycline. Sci. Total Environ. 2020, 708, 135071. [CrossRef]

127. Hitam, C.N.C.; Jalil, A.A. A review on exploration of $\mathrm{Fe}_{2} \mathrm{O}_{3}$ photocatalyst towards degradation of dyes and organic contaminants. J. Environ. Manag. 2020, 258, 110050. [CrossRef] [PubMed]

128. Semeraro, P.; Bettini, S.; Sawalha, S.; Pal, S.; Licciulli, A.; Marzo, F.; Lovergine, N.; Valli, L.; Giancane, G. Photocatalytic Degradation of Tetracycline by $\mathrm{ZnO} / \gamma-\mathrm{Fe}_{2} \mathrm{O}_{3}$ Paramagnetic Nanocomposite Material. Nanomaterials 2020, 10, 1458. [CrossRef] [PubMed]

129. Lian, J.; Ouyang, Q.; Tsang, P.E.; Fang, Z. Fenton-like catalytic degradation of tetracycline by magnetic palygorskite nanoparticles prepared from steel pickling waste liquor. Appl. Clay Sci. 2019, 182, 105273. [CrossRef]

130. Chen, Z.; Gao, Y.; Mu, D.; Shi, H.; Lou, D.; Liu, S.Y. Recyclable magnetic $\mathrm{NiFe}_{2} \mathrm{O}_{4} / \mathrm{C}$ yolk-shell nanospheres with excellent visible-light-Fenton degradation performance of tetracycline hydrochloride. Dalton Trans. 2019, 48, 3038-3044. [CrossRef]

131. Qin, H.; Cheng, H.; Li, H.; Wang, Y. Degradation of ofloxacin, amoxicillin and tetracycline antibiotics using magnetic core-shell $\mathrm{MnFe}_{2} \mathrm{O}_{4} @ \mathrm{C}-\mathrm{NH}_{2}$ as a heterogeneous Fenton catalyst. Chem. Eng. J. 2020, 396, 125304. [CrossRef]

132. Mashayekh-Salehi, A.; Akbarmojeni, K.; Roudbari, A.; van der Hoek, J.P.; Nabizadeh, R.; Dehghani, M.H.; Yaghmaeian, K. Use of mine waste for $\mathrm{H}_{2} \mathrm{O}_{2}$-assisted heterogeneous Fenton-like degradation of tetracycline by natural pyrite nanoparticles: Catalyst characterization, degradation mechanism, operational parameters and cytotoxicity assessment. J. Clean. Prod. 2021, $291,125235$. [CrossRef]

133. Nie, M.; Li, Y.; He, J.; Xie, C.; Wu, Z.; Sun, B.; Zhang, K.; Kong, L.; Liu, J. Degradation of tetracycline in water using $\mathrm{Fe}_{3} \mathrm{O}_{4}$ nanospheres as Fenton-like catalysts: Kinetics, mechanisms and pathways. New J. Chem. 2020, 44, 2847-2857. [CrossRef]

134. Nie, M.; Li, Y.; Li, L.; He, J.; Hong, P.; Zhang, K.; Cai, X.; Kong, L.; Liu, J. Ultrathin iron-cobalt oxide nanosheets with enhanced $\mathrm{H}_{2} \mathrm{O}_{2}$ activation performance for efficient degradation of tetracycline. Appl. Surf. Sci. 2021, 535, 147655. [CrossRef]

135. Yu, J.; Tang, L.; Pang, Y.; Zeng, G.; Wang, J.; Deng, Y.; Liu, Y.; Feng, H.; Chen, S.; Ren, X. Magnetic nitrogen-doped sludge-derived biochar catalysts for persulfate activation: Internal electron transfer mechanism. Chem. Eng. J. 2019, 364, 146-159. [CrossRef]

136. Yu, X.; Lin, X.; Feng, W.; Li, W. Effective Removal of Tetracycline by Using Bio-Templated Synthesis of $\mathrm{TiO}_{2} / \mathrm{Fe}_{3} \mathrm{O}_{4} \mathrm{Heterojunctions}$ as a UV-Fenton Catalyst. Catal. Lett. 2018, 149, 552-560. [CrossRef]

137. Nasseh, N.; Hossein Panahi, A.; Esmati, M.; Daglioglu, N.; Asadi, A.; Rajati, H.; Khodadoost, F. Enhanced photocatalytic degradation of tetracycline from aqueous solution by a novel magnetically separable $\mathrm{FeNi}_{3} / \mathrm{SiO}_{2} / \mathrm{ZnO}$ nano-composite under simulated sunlight: Efficiency, stability, and kinetic studies. J. Mol. Liq. 2020, 301, 112434. [CrossRef]

138. Wang, H.; Chen, T.; Chen, D.; Zou, X.; Li, M.; Huang, F.; Sun, F.; Wang, C.; Shu, D.; Liu, H. Sulfurized oolitic hematite as a heterogeneous Fenton-like catalyst for tetracycline antibiotic degradation. Appl. Catal. B 2020, 260, 118203. [CrossRef]

139. Huang, D.; Zhang, Q.; Zhang, C.; Wang, R.; Deng, R.; Luo, H.; Li, T.; Li, J.; Chen, S.; Liu, C. Mn doped magnetic biochar as persulfate activator for the degradation of tetracycline. Chem. Eng. J. 2020, 391, 123532. [CrossRef]

140. Huang, H.; Guo, T.; Wang, K.; Li, Y.; Zhang, G. Efficient activation of persulfate by a magnetic recyclable rape straw biochar catalyst for the degradation of tetracycline hydrochloride in water. Sci. Total Environ. 2021, 758, 143957. [CrossRef] [PubMed] 
141. Shao, F.; Wang, Y.; Mao, Y.; Shao, T.; Shang, J. Degradation of tetracycline in water by biochar supported nanosized iron activated persulfate. Chemosphere 2020, 261, 127844. [CrossRef]

142. Zhang, P.; Tan, X.; Liu, S.; Liu, Y.; Zeng, G.; Ye, S.; Yin, Z.; Hu, X.; Liu, N. Catalytic degradation of estrogen by persulfate activated with iron-doped graphitic biochar: Process variables effects and matrix effects. Chem. Eng. J. 2019, 378, 122141. [CrossRef]

143. Jiang, X.; Guo, Y.; Zhang, L.; Jiang, W.; Xie, R. Catalytic degradation of tetracycline hydrochloride by persulfate activated with nano Fe0 immobilized mesoporous carbon. Chem. Eng. J. 2018, 341, 392-401. [CrossRef]

144. Li, X.; Jia, Y.; Zhou, M.; Su, X.; Sun, J. High-efficiency degradation of organic pollutants with Fe, N co-doped biochar catalysts via persulfate activation. J. Hazard. Mater. 2020, 397, 122764. [CrossRef]

145. Yu, J.; Kiwi, J.; Zivkovic, I.; Rønnow, H.M.; Wang, T.; Rtimi, S. Quantification of the local magnetized nanotube domains accelerating the photocatalytic removal of the emerging pollutant tetracycline. Appl. Catal. B 2019, 248, 450-458. [CrossRef]

146. Pu, M.; Niu, J.; Brusseau, M.L.; Sun, Y.; Zhou, C.; Deng, S.; Wan, J. Ferrous metal-organic frameworks with strong electrondonating properties for persulfate activation to effectively degrade aqueous sulfamethoxazole. Chem. Eng. J. 2020, $394,125044$. [CrossRef]

147. Ma, Q.; Zhang, H.; Zhang, X.; Li, B.; Guo, R.; Cheng, Q.; Cheng, X. Synthesis of magnetic CuO/MnFe ${ }_{2} \mathrm{O}_{4}$ nanocompisite and its high activity for degradation of levofloxacin by activation of persulfate. Chem. Eng. J. 2019, 360, 848-860. [CrossRef]

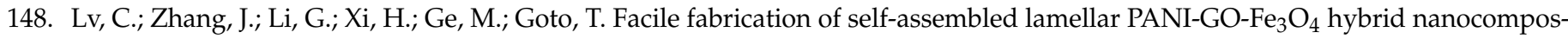
ites with enhanced adsorption capacities and easy recyclicity towards ionic dyes. Colloids Surf. A 2020, 585, 124147. [CrossRef]

149. Tang, S.; Zhao, M.; Yuan, D.; Li, X.; Zhang, X.; Wang, Z.; Jiao, T.; Wang, K. MnFe ${ }_{2} \mathrm{O}_{4}$ nanoparticles promoted electrochemical oxidation coupling with persulfate activation for tetracycline degradation. Sep. Purif. Technol. 2021, 255, 117690. [CrossRef]

150. Ouyang, M.; Li, X.; Xu, Q.; Tao, Z.; Yao, F.; Huang, X.; Wu, Y.; Wang, D.; Yang, Q.; Chen, Z.; et al. Heterogeneous activation of persulfate by $\mathrm{Ag}$ doped $\mathrm{BiFeO}_{3}$ composites for tetracycline degradation. J. Colloid Interface Sci. 2020, 566, 33-45. [CrossRef]

151. He, L.; Zhang, Y.; Zheng, Y.; Jia, Q.; Shan, S.; Dong, Y. Degradation of tetracycline by a novel MIL-101(Fe)/TiO 2 composite with persulfate. J. Porous Mater. 2019, 26, 1839-1850. [CrossRef]

152. Peng, X.; Luo, W.; Wu, J.; Hu, F.; Hu, Y.; Xu, L.; Xu, G.; Jian, Y.; Dai, H. Carbon quantum dots decorated heteroatom co-doped core-shell Fe ${ }^{0} @ P O C N$ for degradation of tetracycline via multiply synergistic mechanisms. Chemosphere 2021, 268, 128806. [CrossRef]

153. Huang, L.; Zeng, T.; Xu, X.; He, Z.; Chen, J.; Song, S. Immobilized hybrids between nitrogen-doped carbon and stainless steel derived $\mathrm{Fe}_{3} \mathrm{O}_{4}$ used as a heterogeneous activator of persulfate during the treatment of aqueous carbamazepine. Chem. Eng. J. 2019, 372, 862-872. [CrossRef]

154. Malakotian, M.; Asadzadeh, S.N.; Khatami, M.; Ahmadian, M.; Heidari, M.R.; Karimi, P.; Firouzeh, N.; Varma, R.S. Protocol encompassing ultrasound $/ \mathrm{Fe}_{3} \mathrm{O}_{4}$ nanoparticles/persulfate for the removal of tetracycline antibiotics from aqueous environments. Clean Technol. Environ. Policy 2019, 21, 1665-1674. [CrossRef]

155. Azalok, K.A.; Oladipo, A.A.; Gazi, M. UV-light-induced photocatalytic performance of reusable MnFe-LDO-biochar for tetracycline removal in water. J. Photochem. Photobiol. A 2021, 405, 112976. [CrossRef]

156. Zhang, Y.; Zhou, J.; Chen, X.; Wang, L.; Cai, W. Coupling of heterogeneous advanced oxidation processes and photocatalysis in efficient degradation of tetracycline hydrochloride by Fe-based MOFs: Synergistic effect and degradation pathway. Chem. Eng. J. 2019, 369, 745-757. [CrossRef]

157. Pang, Y.; Kong, L.; Lei, H.; Chen, D.; Yuvaraja, G. Combined microwave-induced and photocatalytic oxidation using zinc ferrite catalyst for efficient degradation of tetracycline hydrochloride in aqueous solution. J. Taiwan Inst. Chem. Eng. 2018, 93, 397-404. [CrossRef]

158. Ren, F.; Zhu, W.; Zhao, J.; Liu, H.; Zhang, X.; Zhang, H.; Zhu, H.; Peng, Y.; Wang, B. Nitrogen-doped graphene oxide aerogel anchored with spinel $\mathrm{CoFe}_{2} \mathrm{O}_{4}$ nanoparticles for rapid degradation of tetracycline. Sep. Purif. Technol. 2020, 241, 116690. [CrossRef]

159. Guan, R.; Yuan, X.; Wu, Z.; Jiang, L.; Li, Y.; Zeng, G. Principle and application of hydrogen peroxide based advanced oxidation processes in activated sludge treatment: A review. Chem. Eng. J. 2018, 339, 519-530. [CrossRef]

160. Zhao, Q.; Mao, Q.; Zhou, Y.; Wei, J.; Liu, X.; Yang, J.; Luo, L.; Zhang, J.; Chen, H.; Chen, H.; et al. Metal-free carbon materialscatalyzed sulfate radical-based advanced oxidation processes: A review on heterogeneous catalysts and applications. Chemosphere 2017, 189, 224-238. [CrossRef]

161. Zhou, J.; Ma, F.; Guo, H.; Su, D. Activate hydrogen peroxide for efficient tetracycline degradation via a facile assembled carbonbased composite: Synergism of powdered activated carbon and ferroferric oxide nanocatalyst. Appl. Catal. B 2020, $269,118784$. [CrossRef]

162. Lv, S.-W.; Liu, J.-M.; Zhao, N.; Li, C.-Y.; Yang, F.-E.; Wang, Z.-H.; Wang, S. MOF-derived $\mathrm{CoFe}_{2} \mathrm{O}_{4} / \mathrm{Fe}_{2} \mathrm{O}_{3}$ embedded in g-C3N4 as high-efficient Z-scheme photocatalysts for enhanced degradation of emerging organic pollutants in the presence of persulfate. Sep. Purif. Technol. 2020, 253, 117413. [CrossRef]

163. Boczkaj, G.; Fernandes, A. Wastewater treatment by means of advanced oxidation processes at basic $\mathrm{pH}$ conditions: A review. Chem. Eng. J. 2017, 320, 608-633. [CrossRef]

164. $\mathrm{Wu}, \mathrm{Q}$. The fabrication of magnetic recyclable nitrogen modified titanium dioxide/strontium ferrite/diatomite heterojunction nanocomposite for enhanced visible-light-driven photodegradation of tetracycline. Int. J. Hydrogen Energy 2019, 44, 8261-8272. [CrossRef] 
165. Wang, T.; Zhong, S.; Zou, S.; Jiang, F.; Feng, L.; Su, X. Novel Bi2 WO6 -coupled $\mathrm{Fe}_{3} \mathrm{O}_{4}$ Magnetic Photocatalysts: Preparation, Characterization and Photodegradation of Tetracycline Hydrochloride. Photochem. Photobiol. 2017, 93, 1034-1042. [CrossRef]

166. Wang, X.; Wang, A.; Ma, J. Visible-light-driven photocatalytic removal of antibiotics by newly designed $\mathrm{C}_{3} \mathrm{~N}_{4} @ \mathrm{MnFe}_{2} \mathrm{O}_{4}$-graphene nanocomposites. J. Hazard. Mater. 2017, 336, 81-92. [CrossRef] [PubMed]

167. Pi, Z.; Li, X.; Wang, D.; Xu, Q.; Tao, Z.; Huang, X.; Yao, F.; Wu, Y.; He, L.; Yang, Q. Persulfate activation by oxidation biochar supported magnetite particles for tetracycline removal: Performance and degradation pathway. J. Clean. Prod. 2019, 235, 1103-1115. [CrossRef]

168. Zhu, Z.; Tang, X.; Kang, S.; Huo, P.; Song, M.; Shi, W.; Lu, Z.; Yan, Y. Constructing of the Magnetic Photocatalytic Nanoreactor MS@FCN for Cascade Catalytic Degrading of Tetracycline. J. Phys. Chem. C 2016, 120, 27250-27258. [CrossRef]

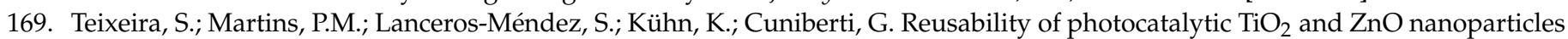
immobilized in poly(vinylidene difluoride)-co-trifluoroethylene. Appl. Surf. Sci. 2016, 384, 497-504. [CrossRef] 